\title{
"EFEITO DOS ÁCIDOS GRAXOS SOBRE A VIA DE SINALIZAÇÃO DA INTERLEUCINA-2 EM LINFÓCITOS HUMANOS"
}

Tese (Doutorado) apresentada ao Instituto de Ciências Biomédicas da Universidade de São Paulo, para obtenção do Título de Doutor em Ciências (Fisiologia).

Área de concentração: Fisiologia

Orientador: Prof. Dr. Rui Curi

São Paulo

2008 


\section{RESUMO}

GORJÃO, R. Efeitos dos ácidos graxos sobre a via de sinalização da interleucina 2 em linfócitos humanos. 2008. 155 f. Tese (doutorado em fisiologia) - Instituto de Ciências Biomédicas, Universidade de São Paulo, São Paulo, 2008.

Neste estudo investigamos os efeitos de concentrações crescentes dos ácidos palmítico (PA), esteárico (SA), oléico (OA), linoléico (LA), docosahexaenóico (DHA) e eicosapentaenóico (EPA) sobre a capacidade proliferativa de linfócitos e as vias intracelulares envolvidas neste processo. Após a determinação das concentrações não tóxicas avaliamos o efeito dos diferentes ácidos graxos (AGs) (50 $\mu \mathrm{M}$ para SA, PA, DHA e EPA e $25 \mu \mathrm{M}$ para OA e LA) sobre a indução da capacidade proliferativa exercida pela IL-2. Posteriormente, a fosforilação das proteínas envolvidas com a via de sinalização intracelular ativada por esta citocina como JAK1 e 3, STAT 5, ERK1/2 e Akt foi avaliada após uma hora de incubação com os AGs. A fosforilação de outra proteína envolvida com proliferação celular, a PKC-zeta, também foi avaliada. A externalização da subunidade alfa do receptor de IL-2 (CD25-alfa) na membrana plasmática foi analisada por citometria de fluxo e a distribuição dos lipid rafts na membrana por microscopia de fluorescência. Os ácidos oléico e linoléico estimularam a proliferação de linfócitos na concentração de $25 \mu \mathrm{M}$ e inibiram-na a partir de $100 \mu \mathrm{M}$, promovendo a morte destas células em $200 \mu \mathrm{M}$. PA e SA inibiram a proliferação a partir de $50 \mu \mathrm{M}$ e promoveram morte celular a partir de $100 \mu \mathrm{M}$. EPA e DHA inibiram a proliferação de linfócitos a partir de 25 e $50 \mu \mathrm{M}$, respectivamente. Ambos foram tóxicos para estas células em 75 $\mu \mathrm{M}$. Quando os linfócitos foram tratados concomitantemente com a IL-2 e os AGs, observou-se que PA, SA, DHA e EPA inibiram o efeito estimulatório sobre a proliferação celular induzido pela IL-2. Estes AGs promoveram diminuição da porcentagem de células na fase S e G2/M e aumento em G1. Por outro lado, OA e LA acentuaram o efeito estimulatório da IL-2. O tratamento dos linfócitos com os AGs levou ao acúmulo de lipídios neutros no interior das células a partir de uma hora de incubação. PA, SA, DHA e EPA inibiram a fosforilação de JAK1, JAK3 e STAT5 induzida pela IL-2 em linfócitos sem alterar a expressão total destas proteínas. OA e LA não exerceram efeito sobre a fosforilação 
destas proteínas. Em relação à cascata da Ras-MAP quinases, EPA, DHA e PA também promoveram diminuição da fosforilação de ERK 1/2 induzida por IL-2, sendo que o efeito do DHA foi mais pronunciado. Por outro lado, OA e LA acentuaram o efeito estimulatório da IL-2 sobre a fosforilação da ERK 1/2. Em relação à via da PI3K-Akt, DHA, EPA, PA e SA promoveram diminuição da fosforilação de Akt e OA e LA não exerceram efeito significativo. Já a fosforilação da PKC-zeta foi estimulada apenas por OA e LA. Este estímulo foi inibido na presença do inibidor da fosfatidilinositol 3 quinase (wortmannin). A porcentagem de células que expressavam CD25 em sua superfície diminuiu nas células tratadas com DHA, SA e PA. Os outros AGs, não exerceram efeito significativo. A expressão total de CD25 não foi alterada por qualquer dos tratamentos. Apenas o DHA promoveu alteração da distribuição de lipid rafts. Os resultados obtidos são sugestivos de que o efeito inibitório sobre a proliferação de linfócitos promovido por PA, SA, DHA e EPA ocorreu devido à diminuição da fosforilação de JAK/STAT, ERK e AKT induzida pela IL-2. Provavelmente, OA e LA estimularam a proliferação de linfócitos aumentando a fosforilação de ERK $1 / 2$ através da ativação de PKC-zeta. A inibição da fosforilação de JAK1, JAK3, STAT 5, ERK1/2 e Akt exercida por DHA está associada a uma alteração na distribuição dos lipid rafts na membrana plasmática.

Palavras-chaves: Ácidos graxos; Sinalização intracelular; Lipid raft; Linfócitos, Interleucina-2, Proliferação. 


\section{ABSTRACT}

GORJÃO R. Regulation of IL-2 signaling by fatty acids in human lymphocytes. 2008. 155 f. PhD thesis (Physiology) - Instituto de Ciências Biomédicas, Universidade de São Paulo, São Paulo, 2008.

The effect of increasing concentrations of palmitic (PA, C16:0), stearic (SA, C18:0), oleic (OA, C18:1,n-9), linoleic (LA, C18:2n-6), docosahexaenoic (DHA, C22:6 n-3) and eicosapentaenoic (EPA, C20:5 n-3) acids on lymphocyte proliferation was investigated. The maximal non-toxic concentrations of these fatty acids for human lymphocytes in vitro were determined. It was also evaluated whether these fatty acids at non-toxic concentrations affect IL-2 induced lymphocyte proliferation and cell cycle progression. Afterwards, the effect of these fatty acids (FA) on interleukin-2 (IL-2) signaling pathway in human lymphocytes was investigated after one hour treatment. Lipid raft distribution was analyzed by fluorescence microcopy. OA and LA increased lymphocyte proliferation at $25 \mu \mathrm{M}$ and at higher concentrations $(75 \mu \mathrm{M}$ and 100 $\mu \mathrm{M})$ inhibited it. Both fatty acids promoted cell death at $200 \mu \mathrm{M}$. PA and SA decreased lymphocyte proliferation at $50 \mu \mathrm{M}$ and promoted cell death at concentrations of $100 \mu \mathrm{M}$ and above. EPA and DHA decreased lymphocyte proliferation at 25 and $50 \mu \mathrm{M}$ respectively, being toxic at $75 \mu \mathrm{M}$. PA, SA, DHA and EPA decreased the stimulatory effect of IL-2 on lymphocyte proliferation, increasing the percentage of cells in $\mathrm{G} 1$ phase and decreasing the proportion of cells in $S$ and $\mathrm{G} 2 / \mathrm{M}$ phases. OA and LA caused an even more pronounced effect. The expression of CD25- $\alpha$ in the cell surface was increased by DHA, SA and PA but it was unaffected by EPA, OA and LA. PA, SA, DHA and EPA decreased JAK1, JAK3, STAT5 and AKT phosphorylation induced by IL-2 but $O A$ and LA did not cause any effect. OA and LA increased ERK1/2 phosphorylation whereas the other FA caused a marked decrease. PKC- $\zeta$ phosphorylation was decreased by OA and LA and it was not altered by the remaining FA. This stimulatory effect was inhibited in the presence of wortmannin (an inhibitor of PI3K). Only DHA altered lipid raft distribution. In conclusion, the inhibitory effect of PA, SA, DHA and EPA on lymphocyte proliferation was due to a decrease in IL-2 activation of JAK/STAT, ERK and AKT pathway activated by IL-2. Probably, OA and LA stimulated lymphocyte 
proliferation by increasing ERK 1/2 phosphorylation throught PKC- $\zeta$ activation. The inhibition of JAK1, JAK3, STAT5, ERK1/2 and Akt phosphorylation caused by DHA is associated to a change in lipid raft distribution.

Key words: Fatty acids; Intracellular signaling; Lipid raft; Proliferation; Lymphocytes; Interleukin 2 


\section{INTRODUÇÃO}

\subsection{Ativação de linfócitos}

A ativação de linfócitos exerce papel importante em muitas patologias, principalmente nas doenças reumáticas. Porcentagens elevadas de linfócitos $T$ são encontradas no sangue periférico de pacientes com lupus eritematoso (CHAN; LAU; ZOLA, 1996; TOKANO et al., 1997), nas articulações inflamadas de pacientes com artrite reumatóide (HIROSE; GOTO; OKUMURA, 1990; FERNANDEZ-GUTIERREZ et al., 1995) e nas glândulas de pacientes com a síndrome de Sjögren (LINDAHL et al., 1985). Drogas que inibem a ativação de linfócitos como a ciclosporina $A$ melhoram o quadro de várias doenças autoimunes (ZEIDLER et al., 1998; FILACI; BACCHETTA; ZANETTI, 1999).

Os linfócitos $T$ podem ser ativados quando reconhecem peptídeos apresentados pelas células apresentadoras de antígeno. Para o reconhecimento dos antígenos, os linfócitos T têm receptores complexos (TCR) que se ligam aos peptídeos específicos e que podem estar ligados à molécula de histocompatibilidade (MHC) na superfície das células apresentadoras de antígenos (APC). Os linfócitos $\mathrm{T} \mathrm{CD8}^{+}$reconhecem os peptídeos ligados a $\mathrm{MHC}$ classe I e os linfócitos T CD4 ${ }^{+}$aqueles ligados a MHC classe II.

Para a ativação efetiva das células T evitando a apoptose, uma ação coestimulatória é requerida. Esta coestimulação pode ser mediada por receptores diferentes, dentre os quais o CD 28 é o mais proeminente, mas vários outros também foram descritos (GREENFIELD; NGUYEN; KUCHROO, 1998; CHAMBERS; ALLISON, 1999; WATTS; DEBENEDETTE, 1999). A estimulação das células $T$ por antígenos, anticorpos anti-CD3 ou lectinas mitogênicas levam a produção de IL-2 e expressão dos receptores de alta afinidade para esta citocina na superfície das células (SMITH, 1988; STANLEY et al., 1990). A ligação da IL-2 ao seu receptor promove proliferação e sobrevivência dos linfócitos T (TKACZUK et al., 2002).

\subsubsection{Vias de sinalização desencadeadas pela estimulação do TCR}


O complexo TCR existe em duas formas distintas, TCR $\alpha \beta$ e TCR $\gamma \delta$, que definem as diferentes linhagens de células T. Além destes heterodímeros, existem as cadeias do complexo CD3 chamadas de $\gamma, \delta, \varepsilon$ e $\xi$. Esta última é representada duas vezes em cada complexo. Os co-receptores CD4 ou CD8 também fazem parte deste complexo (ARINGER, 2002; OKKENHAUG et al., 2004) (Figura 1).

As cadeias TCR $\alpha$ e $\beta$ ligam-se a antígenos específicos apresentados como peptídeos pelas moléculas do MHC, enquanto que o CD4 reconhece a própria molécula do MHC II, ocorrendo o mesmo entre CD8 e MHC I. Os TCRs ligam-se com eficiências variadas aos peptídeos apresentados. Os efeitos desta variabilidade na ligação antígeno-TCR parecem seguir um modelo cinético. Neste modelo, várias etapas de fosforilações consecutivas que culminam em uma resposta celular ocorrem. Estas etapas não se completam se a ligação do receptor ao antígeno for muito fraca para promover uma associação estável por tempo suficiente. Desta forma, outros elementos também estão envolvidos neste mecanismo de ativação.

A multifosforilação de tirosinas das ITAMs (immunoreceptor tyrosinebased activation motif) localizadas na cadeia $\xi$ do CD3 exercem papel fundamental no processo de ativação dos linfócitos (Figura 1). As ITAMs consistem de duas repetições, cada uma contém um resíduo de tirosina e uma lisina nas posições 1 e 4, respectivamente, e de seis a oito aminoácidos espaçadores entre eles. As cadeias CD3 $\gamma, \delta$ e $\varepsilon$ contêm uma ITAM cada; cada cadeia $\xi$ carrega três delas (KERSH; SHAW; ALLEN, 1998).

As ITAMs tornam-se sítios de ancoramento de proteínas logo que seus resíduos de tirosina são fosforilados pelas proteínas Lck (ligadas pelos receptores CD4 ou CD8) ou Fyn, pertencentes à famíla das proteínas quinases Src. Estas duas quinases, sozinhas ou em combinação, atuam na primeira etapa de sinalização do TCR. Entretanto, ambas as quinases são auxiliadas por uma fosfatase, chamada de molécula CD45, que é essencial para a ativação da célula T. Esta fosfatase remove um fosfato da tirosina carboxiterminal das quinases. 
A Lck interage com a porção citoplasmática dos co-receptores CD4 e CD8. Estes receptores ligam-se às moléculas do MHC nas APCs durante a apresentação do antígeno, trazendo a Lck para próximo do TCR, facilitando a fosforilação das ITAMs (RAZZAQ et al., 2004). A importância da proteína Lck na via de sinalização do TCR foi demonstrada em camundongos deficientes para o gene que codifica esta proteína. Nestes animais foi observada diminuição da capacidade proliferativa das células $T$ quando estimuladas no TCR (MOLINA et al., 1993).

As próximas etapas após a ativação de Lck e Fyn envolvem as proteínas tirosina quinases ZAP-70 e Syk. Estas proteínas ligam-se às ITAMs com ambas as tirosinas fosforiladas. Através deste processo de ligação, Syk é imediatamente ativada, enquanto que ZAP-70 requer fosforilação adicional de seus resíduos de tirosina pela família das proteínas quinases Src. Em humanos, a ausência de ZAP-70, como observado em alguns pacientes, leva a uma imunodeficiência severa caracterizada por perda de $\mathrm{CD}^{+}$enquanto que células $\mathrm{CD}^{+}$maduras não respondem a estimulação de TCR (ARPAIA et al., 1994; CHAN; DESAI; WEISS, 1994).

Nas vias posteriores à ativação de Syk e ZAP-70, as proteínas LAT (linker for activation of $T$ cells), SLP-76 e fosfolipase C $\gamma 1$ (PLC $\gamma 1$ ) são fosforiladas (OKKENHAUG et al., 2004). LAT é uma proteína adaptadora transmembrânica que recruta o complexo SLP-76/Vav, PLC $\gamma 1$, fosfatidilinositol 3-quinase (PI3K) (SASAKI et al., 2002), a proteína adaptadora Grb2 e outras moléculas sinalizadoras para a membrana celular (ARINGER, 2002). Este processo leva ao surgimento de microdomínios ricos em glicolipídios que são necessários para que ocorra a sinalização de forma eficiente.

SLP 76 é uma proteína adaptadora que se liga a Vav e Nck. Vav é um fator de troca do nucleotídeo guanina para as GTPases Rac e Rho, que estão envolvidas com a ativação de ERK e NF-אB (COSTELLO et al., 1999). Vav é ativada pela família das quinases Src através da fosforilação em tirosina (AGHAZADEH et al., 2000). Nck é uma proteína adaptadora que recruta a quinase de serina/treonina Pak, proteína essencial para a reorganização de actina e proliferação induzida pelos sinais de TCR. A SLP-76 leva à ativação de Ras, onde a proteína Grb2 e o fator de troca de guanina Sos também exercem 
papel fundamental neste processo (LAW; SIDORENKO; CLARK, 1994). Isto leva à ativação consecutiva de Raf, proteína quinase quinase ativada por mitógeno (MEK) e quinase regulada por sinal extracelular (ERK). A ação de enzimas, das moléculas adaptadoras e de segundos mensageiros de forma coordenada promove aumento da atividade de fatores de transcrição como (NF)-AT, AP-1 e NF-kB e expressão de proteínas como CD69, CD25 e IL-2 (RAZZAQ et al., 2004) (Figura 1).

Finalmente, SLP-76 é requerida para a ativação de fosfolipase C (PLC)- $\gamma$, onde outras moléculas adaptadoras parecem exercer papel fundamental. Desta forma, PLC leva à produção resultante de $\mathbb{I P}_{3}$ e diacilglicerol (DAG). Estes segundos mensageiros induzem aumento da concentração de $\mathrm{Ca}^{2+}$ intracelular e ativação da proteína quinase $C$ (PKC) (ARINGER, 2002). Os membros da família da PKC podem levar à ativação de NF-kB resultando em aumento da expressão de IL-2 e CD25 (MANICASSAMY; GUPTA; SUN, 2006).

Sob algumas circunstâncias, através da estimulação com lectinas mitogênicas e anticorpos anti-CD3, o processo de ativação da PLC e aumento intracelular de $\mathrm{Ca}^{2+}$ parecem ser obrigatórios para que ocorra a secreção de IL2. Entretanto na presença de ester de forbol e em certas linhagens mutantes de linfócitos $\mathrm{T}$, a secreção de IL-2 parece ser independente da PLC e do conseqüente aumento da concentração de $\mathrm{Ca}^{2+}$ intracelular (STANLEY et al., 1990). Já o aumento no conteúdo de fosfotirosina é uma etapa obrigatória para que ocorra a produção de IL-2. A pré-incubação dos linfócitos T com inibidor de tirosina quinase promove inibição total da produção de IL-2 por estas células (STANLEY et al., 1990).

\subsubsection{Regulação da sinalização de TCR pelos microdomínios de membrana}

Lipid rafts são microdomínios especializados existentes na membrana plasmática com uma composição lipídica que é diferente da bicamada rica em glicerofosfolipídios. Os lipid rafts são ricos em glicoesfingolipídios, esfingomielina e colesterol que é um componente estrutural 
fundamental. A formação destes rafts na membrana pode ser regulada pelo tipo e concentração de lipídios presentes na bicamada lipídica. $\mathrm{O}$ agrupamento de miristato e palmitato na porção $\mathrm{N}$-terminal de Lck promove a ancoragem desta proteína na membrana e governa o seu direcionamento para os lipid rafts (KOEGL et al., 1994; KABOURIDIS; MAGEE; LEY, 1997). Além desta proteína, a molécula adaptadora LAT também está localizada nestas regiões (BRDICKA; CERNY; HOREJSI, 1998).

Uma lista de moléculas sinalizadoras, além de Lck e LAT, parece translocar para os microdomínios de membrana após estimulação de TCR. O receptor $\mathrm{CD}^{+}$está ligado aos lipid rafts através de interações com Lck e de sua palmitoilação nos dois resíduos de cisteína próximos à membrana (FOTI et al., 2002) (FRAGOSO et al., 2003). A estimulação de $C D 4^{+}$promove indução de agregação dos lipid rafts e aumento dos agrupamentos moleculares na sinapse imunológica (FRAGOSO et al., 2003; BALAMUTH; BROGDON; BOTTOMLY, 2004).

A ativação das células T por super antígenos é mediada por eventos sinalizadores que ocorrem nos microdomínios da membrana (PIZZO et al., 2004). Acredita-se que a afinidade dos TCRs pelos domínios de lipid rafts aumenta após a sua estimulação. No entanto, esta situação não está bem esclarecida, pois ainda não existem evidências ligando a ativação de vias de sinalização com o aumento da afinidade de TCR aos lipid rafts (RAZZAQ et al., 2004).

A importância dos lipid rafts na sinalização dos TCRs foi sugerida a partir de experimentos onde as células $T$ foram tratadas com agentes depletores de colesterol como a metil- $\beta$-ciclodestrina e observou-se inibição das vias de sinalização, por rompimento dos lipid rafts (XAVIER; SEED, 1999).

Outras moléculas que participam da via de sinalização do TCR e que são recrutadas para estes microdomínios são ZAP-70 e a PLC 11 (JANES; LEY; MAGEE, 1999; VERI et al., 2001). O substrato para a PLC, PIP 2 está presente em grande quantidade nos lipid rafts, sugerindo que estes microdomínios representam o principal sítio de ação da PLC (LIU et al., 1998). As proteínas Grb2 e Sos que regulam a atividade de Ras também são recrutadas para estas 
regiões (FINCO et al., 1998), assim como a PKC $\theta$ que exerce papel fundamental na via de estimulação do NF-אB (KHOSHNAN et al., 2000). Além da presença de proteínas tirosina quinases envolvidas com a via de ativação do TCR, existem também fosfatases associadas aos lipid rafts e que exercem papel fundamental nos processos de ativação dos linfócitos (RAZZAQ et al., 2004).

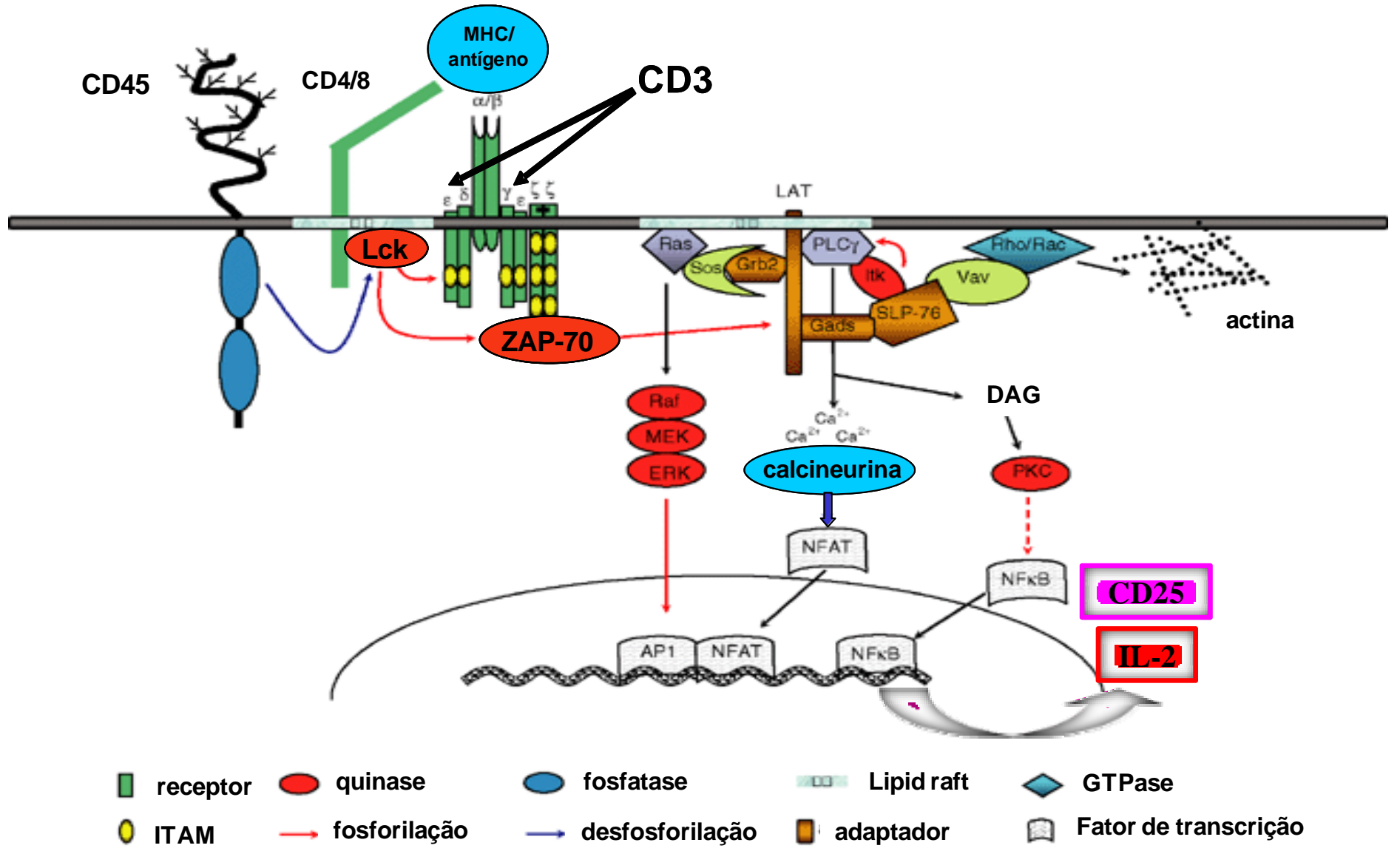

Figura 1- Cascatas de sinalização estimuladas pelo TCR. Representação esquemática dos principais componentes da cascata de sinalização desencadeada pelo reconhecimento de um antígeno pelo TCR (RAZZAQ et al., 2004). AP-1, proteína ativadora 1; DAG, diacilglicerol; ERK, quinase regulada por sinal extracelular; LAT, linker for activation of $T$ cell; Lck, proteína tirosina quinase específica de leucócitos; MEK, proteína quinase quinase ativada por mitógeno; MHC, molécula de histocompatibilidade; $\mathrm{NF}$, fator nuclear; PLC, fosfolipase C; PKC, proteína quinase C; SLP-76, proteína 76 kD específica de leucócitos; Sos, son of sevenless; ZAP-70, proteína $70 \mathrm{kD}$ associada à cadeia zeta. 
A IL-2 é uma citocina secretada pelos linfócitos $T$ quando ocorre estimulação por antígenos, lectinas e anticorpos anti-CD3 que está relacionada com a regulação de aspectos importantes do metabolismo de linfócitos, proliferação e diferenciação. A IL-2 foi o primeiro fator de crescimento de célula $\mathrm{T}$ a ser molecularmente clonado sendo a citocina de escolha para a propagação das células T em cultura (SMITH, 1988). Esta citocina é infundida em pacientes com AIDS para aumentar o número e a função de células $T$ (PAHWA; MORALES, 1998).

A produção de IL-2 ocorre quando há estímulo do TCR ativando vias de sinalização que foram descritas no ítem anterior. Outras vias que regulam a produção e secreção de IL-2 têm sido descritas nos últimos anos. Algumas das proteínas envolvidas neste processo são as caspases. A incubação de linfócitos humanos com bloqueadores de caspases promove inibição da produção de IL-2 e da atividade do fator de transcrição NF-kB, levando a uma diminuição da capacidade proliferativa destas células (FALK et al., 2004).

\subsubsection{Receptor de IL-2 (IL-2R)}

A IL-2 liga-se a receptores de superfície nas células (IL-2R) levando à ativação dos linfócitos T (TKACZUK et al., 2002). A ligação da IL-2 ao seu receptor promove o início da proliferação da célula $T$ regulando a transição da fase $G_{1}$ para a $S$ do ciclo celular (WANG et al., 2004) nos linfócitos ativados.

O IL-2R é composto pelas cadeias $\alpha$ (CD25), $\beta$ (CD122) e $\gamma$ (CD132) que se ligam a IL-2 com diferentes afinidades, sendo que a afinidade máxima ocorre quando as três cadeias estão presentes; afinidade intermediária quando apenas as cadeias $\beta$ e $\gamma$ estão presentes e pouca afinidade quando apenas a subunidade $\alpha$ está presente (TKACZUK et al., 2002). O IL-2R é modificado pelo estado de ativação da célula $T$, visto que os linfócitos circulantes inativos, ou seja, em repouso, expressam apenas as cadeias $\beta$ e $\gamma$ (HATAKEYAMA et al., 1989). Quando o antígeno é reconhecido pelo TCR, a cadeia $\alpha$ é expressa combinando com as cadeias $\beta$ e $\gamma$ para formar o receptor de alta afinidade (KACZMAREK; CALABRETTA; BASERGA, 1985), ocorrendo aumento da sensibilidade da célula a IL-2 (Figura 2). As cadeias $\beta$ e $\gamma$ são responsáveis 
pela transmissão do sinal desencadeado pela ligação da IL-2 ao receptor, pois a porção citoplasmática destas cadeias apresenta sítios de ligação para outras proteínas. Já a cadeia $\alpha$ apresenta uma porção citoplasmática curta e não participa da transmissão do sinal sendo apenas fundamental para a ligação da IL-2 ao seu receptor.
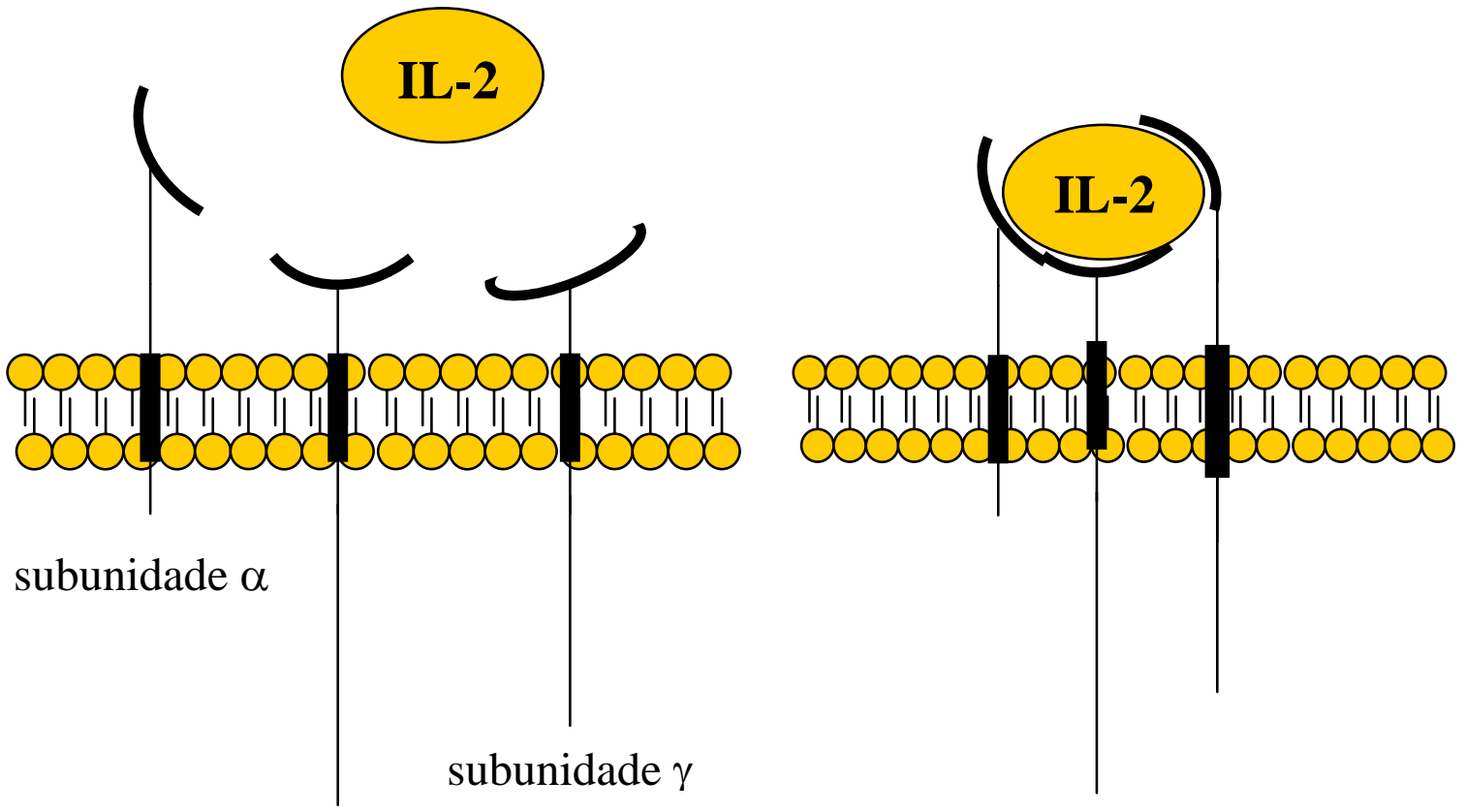

subunidade $\beta$

Figura 2- Ligação da IL-2 ao IL-2R promove heterodimerização das subunidades $\beta$ e $\gamma$.

A principal via de sinalização ativada pela ligação da IL-2 ao seu receptor (IL-2R) é a JAK/STAT. A sinalização intracelular pelo IL-2R também pode envolver a ativação de outras vias para a ativação completa dos linfócitos, como das proteínas Ras-Raf1-ERK1/2 (SATOH et al., 1991; TURNER et al., 1991; GRAVES et al., 1992), (KARNITZ et al., 1995) e PI3K-Akt (AUGUSTINE; SUTOR; ABRAHAM, 1991) (Figura 3).

Um domínio próximo à região da membrana (domínio PROX) da subunidade $\gamma$ promove ativação de Ick. Esta proteína pode estimular a PI3K desencadeando a ativação da Akt ou proteína quinase B (mecanismo descrito posteriormente) resultando na proteção contra a ocorrência de apoptose 
(ELLERY; NICHOLLS, 2002). No entanto, esta via não é a principal responsável pela ativação de PI3K. Além disso, este mecanismo é importante para a sobrevivência das células na circulação periférica, mas não permite que ocorra proliferação.

Quando os linfócitos estão no estado de repouso, a expressão da proteína JAK3 é suprimida e em muitos casos só é ativada após estimulação do IL-2R. Para que os linfócitos proliferem a expressão de JAK3 é fundamental. Quando os linfócitos são estimulados através do TCR ocorre indução da expressão de JAK3 juntamente com a subunidade CD25 levando à formação do receptor de alta afinidade que responde completamente à ação da IL-2 (ELLERY; NICHOLLS, 2002).

\subsubsection{Via JAKISTAT}

Após a ligação da IL-2 ao receptor, ocorre heterodimerização das subunidades $\beta$ e $\gamma$ ativando a transfosforilação das proteínas associadas Janus Kinase 1 (JAK1) e JAK3 respectivamente (RUSSELL et al., 1994; KIRKEN et al., 1995). As JAKs ativadas fosforilam resíduos de tirosina do receptor criando sítios de ligação para os fatores ativadores de trancrição STAT5a/b que possuem domínio $\mathrm{SH}_{2}$. As JAKs fosforilam STAT nos resíduos de tirosina promovendo a sua dissociação do receptor. A seguir, os STATs dimerizam-se e translocam-se para o núcleo ligando-se a sequências específicas do DNA estimulando a transcrição gênica. A ação dos STATs sobre a transcrição gênica resulta no controle do crescimento celular, diferenciação e resposta imune (RUSSELL et al., 1994). No núcleo existe atividade tirosina fosfatase que bloqueia o processo de ativação da transcrição pela desfosforilação dos STATs, que são exportados novamente para o citoplasma (HASPEL; DARNELL, 1999).

Embora a fosforilação em tirosina dos STATs seja fundamental para a sua ativação, a fosforilação nos resíduos de serina também regula a sua atividade transcricional (ZHANG et al., 1995; PARK et al., 2001) alterando a expressão de genes ativados por este fator de transcrição. O STAT 5a pode ser fosforilado em dois sítios de serina $\operatorname{Ser}^{725}$ e $\operatorname{Ser}^{779}$ e o STAT 5 b pode ser 
fosforilado na $\operatorname{Ser}^{730}$ (PARK et al., 2001). A fosforilação em serina dos STAT5 foi observada em células e tecidos estimulados por ligantes como $\mathrm{GH}$ (DINERSTEIN-CALI et al., 2000), prolactina (KIRKEN et al., 1997) e IL-2 (BEADLING et al., 1996). Nos linfócitos $T$ tratados com inibidor de serina quinase $\mathrm{H} 7$, que bloqueia a fosforilação de serina do STAT5, observou-se que a atividade transcricional de STAT5 estimulada por IL-2 foi abolida (BEADLING et al., 1996).

A ativação de STAT pode ser inibida por fatores antagonistas (DARNELL, 1998) sugerindo que existem vias responsáveis pela inibição da sinalização JAK/STAT (SENGUPTA; SCHMITT; IVASHKIV, 1996). Os mecanismos responsáveis pela inibição da atividade de STAT incluem desfosforilação, degradação proteolítica ou associação com moléculas inibitórias (KIM; MANIATIS, 1996; SHUAI; LIAO; SONG, 1996; CHUNG et al., 1997). Alguns deles ocorrem através da ativação da proteína quinase $A$ ou proteína quinase C (DAVID et al., 1995; PETRICOIN et al., 1996), ativação do fluxo de cálcio (SENGUPTA; SCHMITT; IVASHKIV, 1996) e ação de citocinas antagonistas como TGF $\beta$ (BHAT; ZHANG, 1996). O mecanismo mais clássico de inibição de STAT5 é através do feedback negativo mediado pela família de proteínas SOCS (supressores de sinalização de citocinas) (KOVANEN; LEONARD, 1999).

O primeiro membro descrito da família SOCS foi denotado como CIS (proteína contendo domínio SH2 induzida por citocina) (MATSUMOTO et al., 1997). CIS compete com STAT5 pelo mesmo resíduo de tirosina fosforilado. Desta forma, CIS inibe a sinalização de JAK/STAT interagindo com o receptor de citocina ativada. A expressão de SOCS1 também é fortemente induzida pela IL-2 e esta proteína pode associar-se com o receptor da IL-2 inibindo fortemente a função de STAT5, sugerindo que SOCS1 exerce papel fundamental na regulação da resposta imune (PAUKKU; SILVENNOINEN, 2004).

\subsubsection{Sinalização por Ras}

As JAKs ativadas fosforilam os resíduos de tirosina na subunidade $\beta$ do IL-2R que também servem de sítios de ligação para Shc. A fosforilação de 
Shc em resposta a IL-2 requer a expressão da subunidade $\beta$ do IL-2R (DORSCH; HOCK; DIAMANTSTEIN, 1994). Shc parece interagir com Y-388 na subunidade $\beta$ quando este está fosforilado, permitindo a sua interação com outra proteína adaptadora, Grb-2 (RAVICHANDRAN et al., 1996). Y-388 é fosforilado apenas na presença de JAK3, sendo que na ausência desta proteína a fosforilação de Shc não ocorre (ELLERY; NICHOLLS, 2002). Shc recruta dois complexos protéicos importantes: Grb-2/Sos que ativa a via da Ras/ERK e Grb-2/Gab-2 que ativa a via da PI3K (IZQUIERDO PASTOR; REIF; CANTRELL, 1995).

A proteína Shc é recrutada pelo $\mathrm{IL}-2 \mathrm{R} \beta$ ativado tornando-se fosforilada em três sítios de tirosina (GOTOH; TOJO; SHIBUYA, 1996). Estes sítios de fosforilação permitem a ligação dos domínios $\mathrm{SH} 2$ da proteína Grb2. Através do seu domínio SH3, Grb2 liga-se a proteína Sos que ativa Ras e consequentemente promove ativação da via das MAP quinases (SEGER et al., 1995). A proteína Sos é responsável por catalisar a ligação de GTP às proteínas Ras que são ativas quando ligadas ao GTP e inativas quando estão ligadas ao GDP (CHARDIN et al., 1993). A proteína Sos pertence aos fatores conhecidos como GEFs (fatores de troca de GTP) que catalisam esta ligação de GTP às proteínas Ras (BOKOCH; DER, 1993).

As ERKs constituem uma família de MAP quinase que participam da fase final desta via de sinalização e que fosforilam outras quinases e proteínas regulatórias da transcrição (BOULTON et al., 1991; MARSHALL, 1995). As ERKs podem também estar envolvidas com a fosforilação de resíduos de serina do STAT em vários sistemas (DAVID et al., 1995; WEN; DARNELL, 1997). Na sinalização de GH que também envolve ativação de STAT 5 a via da ERK é fundamental para a atividade transcricional do STAT (PIRCHER et al., 1999), (PARK et al., 2001). As ERKs estão envolvidas com a fosforilação e ativação de fatores de transcrição como Elk-1, Fos, AP-1, NF-AT e c-myc (TREISMAN, 1996; GENOT; CANTRELL, 2000) aumentando a capacidade proliferativa das células. 


\subsubsection{Sinalização por PI3K}

A ativação de Grb2 também medeia a tirosil-fosforilação de Gab2 formando um complexo que promove ativação de PI-3 quinase (GU et al., 2000). Esta proteína promove a síntese de PIP3 a partir de fosfatidilinositol de membrana. A proteína Akt contém um domínio PH (Pleckstrin homology) que se liga ao $\mathrm{PIP}_{3}$ na membrana. Em seguida, a conformação da Akt pode ser alterada e ativada por processo que requer fosforilação por uma proteína quinase dependente de fosfatidilinositol (PDK), em dois sítios, um no loop de ativação (Thr308) e o outro na porção carboxi-terminal (Ser473), evento que ocorre na membrana celular (DU; TSICHLIS, 2005). A fosforilação em Ser473 precede e facilita a fosforilação em Thr308 (SARBASSOV et al., 2005). Quando ativada, a Akt retorna para o citoplasma ou migra para o núcleo onde fosforila uma variedade de proteínas envolvidas com o processo de sobrevivência das células. A proteína Akt induz expressão de genes como bcl-2, bcl-xL e c-myc, que são anti-apoptóticos, e inibe a ativação de proteínas pró-apoptóticas como Bad, Bid e Bax, promovendo a sobrevivência das células T (LORD et al., 1998; 2000).

A ativação da via da PI3K pode potencializar a sinalização proliferativa por STAT5 através de eventos paralelos à convencional via das ciclinas G1. Esta potencialização não é resultado de aumento da quantidade de STAT5 ativado nem da atividade transcricional de STAT5. Isto é demontrado através da indução máxima da expressão de c-myc, ciclina D2, ciclina D3, ciclina E e bcl-xL promovida pela via da PI3K-Akt (MOON, 2001). A via de sinalização da PI3K isoladamente não é capaz de induzir proliferação, mas atua potencializando os sinais mitogênicos de outras vias e na manutenção da célula viva. Células com atividade elevada de PI3K podem ser mais sensíveis aos estímulos mitogênicos do que aquelas cuja atividade da PI3K foi inibida (MOON, 2001). 


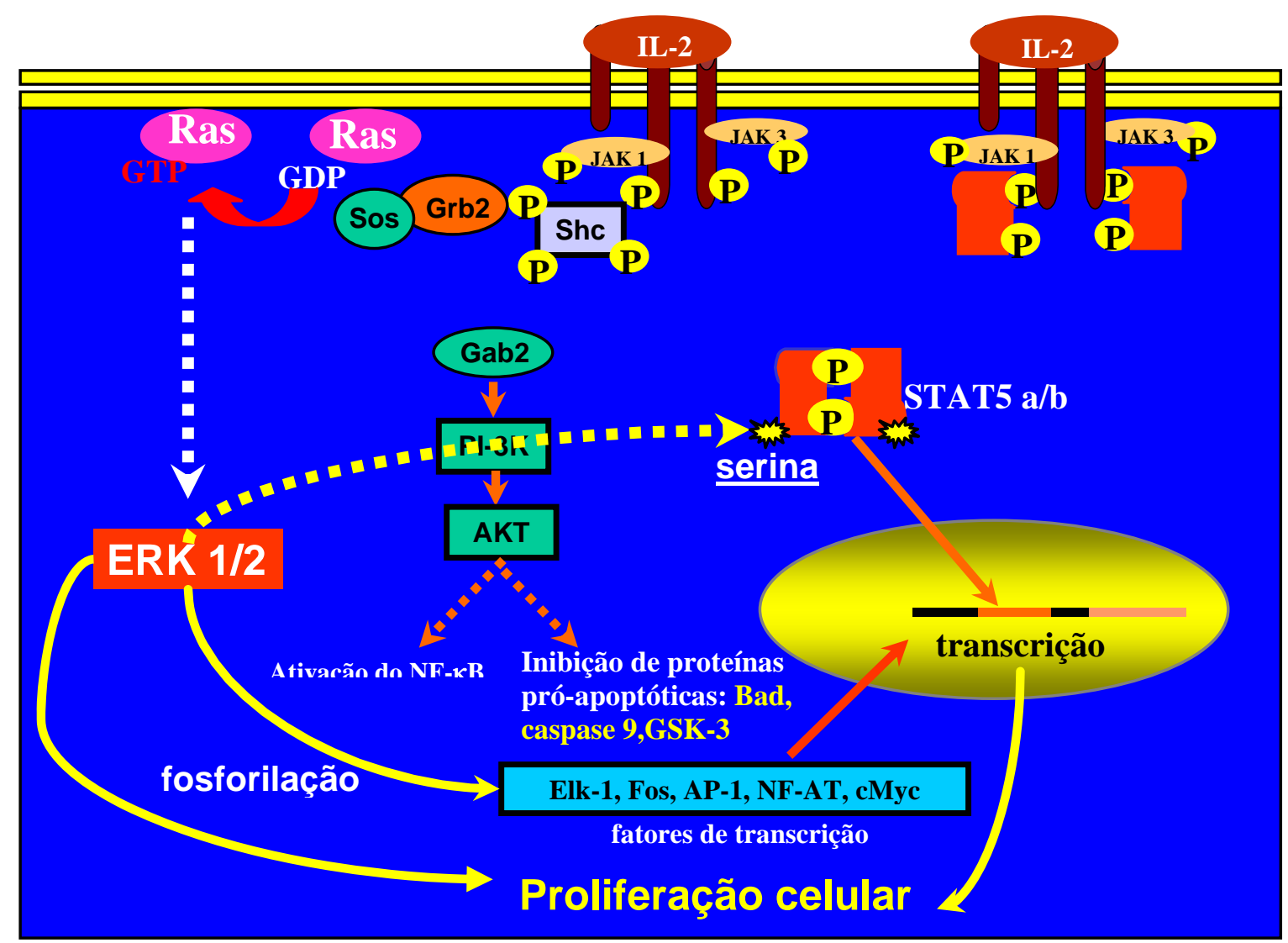

:igura 3- Sinalização intracelular desencadeada pela ativação do receptor de IL-2 (IL-2R). A ligação da IL-2 ao seu receptor ativa a transfosforilação das proteínas JAK 1 e 3 que fosforilam os resíduos de tirosina da porção intracelular das subunidades $\beta$ e $\gamma$ do receptor criando sítios de ligação para os fatores de trancrição STAT 5 a e b. Estes fatores deslocam-se para o núcleo ativando a transcrição de genes. A fosforilação de resíduos de tirosina na subunidade $\beta$ do IL-2R também recruta Shc que é fosforilada permitindo a ligação de Grb2 que liga-se pelo domínio SH3 a Sos ativando Ras e consequentemente a via das Map quinases. A ERK ativada fosforila fatores de transcrição que induzem a expressão de genes relacionados com proliferação celular. Gab2 também é ativado pela Grb2 que ativa a via PI3KAkt. Esta última proteína induz a expressão de genes anti-apoptóticos, regulando a proliferação e sobrevivência da célula.

\subsubsection{A via da proteína quinase C (PKC)}

A ativação da PKC pela IL-2 parece ser um mecanismo importante pelo qual esta citocina suprime os sinais de morte celular em linfócitos T. As respostas celulares induzidas pela ativação das PKCs resultam na fosforilação de proteínas alvo em resíduos de serina/treonina, modulando desta forma diferentes processos celulares (FAN; KARNOVSKY, 2000; KOBAYASHI et al., 2001). As famílias das PKCs são classificadas em três grupos de acordo com os co-fatores necessários para a sua ativação. As PKCs convencionais ( $\alpha, \beta$ e 
$\gamma$ ) são ativadas por $\mathrm{Ca}^{2+}$, DAG e fosfatidilserina, um fosfolipídio de membrana. As PKCs novas $\left(\delta, \varepsilon\right.$ e $\theta$ ) não têm o domínio de ligação ao $\mathrm{Ca}^{2+}$ e são ativadas por DAG, fosfatidilserina e ácidos graxos insaturados. As PKCs atípicas ( $\zeta$ e $\lambda / \imath$ ) não são ativadas por $\mathrm{Ca}^{2+}$ e DAG, mas são ativadas por fosfatidilserina, fosfatidilinositóis ou ácidos graxos insaturados (NAKANISHI; EXTON, 1992; NAKANISHI; BREWER; EXTON, 1993; SELBIE et al., 1993). DUTIL et al. (1994) demonstraram que a ativação das PKCs também é regulada por fosforilação, sendo este um bom indicador de ativação destas proteínas. A PKC- $\zeta$ é fosforilada pela PDK1, mas recentemente observou-se que PIP3 pode ativar a PKC- $\zeta$ diretamente (YANEY; KORCHAK; CORKEY, 2000).

A ativação da PKC pela IL-2 parece ser um mecanismo importante pelo qual esta citocina suprime os sinais de morte celular em linfócitos T. A IL-2 também pode ativar PKC sem alterar a sua translocação do citosol para a membrana (LU; MORLEY; DURKIN, 1999). Lu et al. (1999) observaram que a ativação da PKC residente na membrana em uma linhagem de linfócitos $T$ citotóxicos (CTLL-2) induzida pela IL-2 não está relacionada com o aumento da atividade de tirosina quinase promovida por esta citocina. Uma porção significativa da PKC presente nas células associa-se à membrana no estado inativo e este pool pode ser especificamente estimulado por fatores de crescimento (como a IL-2) na ausência de translocação para a membrana plasmática.

A produção de DAG e ácido araquidônico (AA) pelas células estimuladas com IL-2 também aumenta, sem elevação concomitante de IP3 e $\mathrm{Ca}^{2+}$ (LU; MORLEY; DURKIN, 1999). Tanto o AA como DAG estimulam a atividade de uma família de PKC de maneira independente de fosfolipídios e $\mathrm{Ca}^{2+}$ (as novas) (LESTER et al., 1991). A inibição da $\mathrm{PLA}_{2}$, que é responsável pela liberação de $A A$ da membrana, promove inibição da atividade de PKC estimulada por IL-2 (LU; MORLEY; DURKIN, 1999). Portanto, a IL-2 pode ativar dois mecanismos distintos: sinalização envolvendo ativação de tirosina quinase e a estimulação da atividade de PKC resultando em aumento da proliferação celular e inibição do processo de apoptose. 


\subsection{Proteínas fosfatases e ativação de linfócitos}

As vias de sinalização celular são reguladas por fosforilação /desfosforilação de proteínas. A adição ou remoção do grupamento fosfato de uma proteína pode gerar um local de reconhecimento para a interação proteína-proteína, controle da estabilidade protéica e o mais importante modular a atividade de enzimas (ZHANG et al., 2003). Aproximadamente 30\% das proteínas celulares são fosfoproteínas (COHEN, 1982). Em células eucarióticas a maior parte da fosforilação de proteínas ocorre em resíduos de serina e treonina. Fosforilação em resíduos de tirosina representa somente 0,01-0,05\% do total de proteínas fosforiladas (SWANSON; ALEX; SIMON, 1994).

Historicamente, proteínas fosfatases constituem uma grande família de enzimas com analogia semelhante a proteínas quinases em sua complexidade e diversidade estrutural. Portanto, estas proteínas exercem efeitos tanto negativo quanto positivos nas vias de sinalização e no controle fisiológico de uma variedade de tecidos (ZHANG; ZHOU; XIE, 2002). Mudanças anormais na atividade dessas enzimas podem proporcionar conseqüências graves, que incluem neoplasias e doenças resultantes de defeitos imunológicos (JIA, 1997; HARRISON; WANG; STUDZINSKI, 1999).

As proteínas fosfatases têm auxiliado na elucidação muitos eventos celulares dependentes de desfosforilação e fosforilação envolvidos nas funções de linfócitos. Estas células expressam uma variedade de proteínas tirosina fosfatases citoplasmáticas e de membranas (PALOU et al., 1997; MUSTELIN et al., 2004) conforme mostrado na Tabela 1. 
Tabela 1. Proteínas fosfatases que participam dos processos de sinalização em linfócitos humanos.

\begin{tabular}{|c|c|c|}
\hline FOSFATASE & TIPO DE REGULAÇÃO & $\begin{array}{l}\text { PROTEÍNAS } \\
\text { REGULADAS }\end{array}$ \\
\hline CD25 & Positiva & $\begin{array}{l}\text { Família das proteínas } \\
\text { quinases Lck e Fyn }\end{array}$ \\
\hline TCPTP & Negativa & $\begin{array}{l}\text { Desfosforila STAT nos } \\
\text { núcleos celulares }\end{array}$ \\
\hline SHP2 & Positiva & $\begin{array}{c}\text { Aumenta a fosforilação } \\
\text { de ERK por mecanismo } \\
\text { desconhecido }\end{array}$ \\
\hline PAC1 & Negativa & $\begin{array}{l}\text { Desfosforila ERK em } \\
\text { núcleo de células; }\end{array}$ \\
\hline PTEN & Negativa & $\begin{array}{c}\text { Neutraliza PI3K } \\
\text { reduzindo a } \\
\text { sobrevivência }\end{array}$ \\
\hline Calcineurina & ------ & $\begin{array}{l}\text { Fosfatase citoplasmática } \\
\text { de grande importância } \\
\text { na transdução de sinal. }\end{array}$ \\
\hline
\end{tabular}

\section{4 Ácidos graxos}

Os ácidos graxos (AGs) são compostos formados por uma cadeia hidrocarbonada e um grupamento carboxila e podem ser classificados como saturados ou insaturados (quando apresentam pelo menos uma dupla ligação). 
Os AGs podem ser esterificados e formar triacilgliceróis, fosfolipídios, ésteres de colesterol, proteínas aciladas ou ceramidas.

Os mamíferos podem sintetizar ácidos graxos a partir de acetil-CoA - síntese de novo de AGs. O produto final da enzima ácido graxo sintetase é o ácido palmítico (16:0), o qual pode ser elongado a ácido esteárico (18:0) e a outros ácidos de cadeia longa como o eicosanóico (20:0), be-hênico (22:0) e lignocérico (24:0). A enzima $\Delta^{9}$ dessaturase está presente em plantas e animais e introduz uma dupla ligação entre o $\mathrm{C}_{9}$ e $\mathrm{C}_{10}$, convertendo o ácido esteárico em oléico (18:1, n-9), com uma única insaturação na nona posição a partir do hidrocarboneto terminal. Estes ácidos graxos além de serem sintetizados pelos mamíferos, também são obtidos na dieta.

Há um grupo de ácidos graxos, denominados essenciais, que só podem ser obtidos pela dieta (POMPEIA et al., 2000). As principais insaturações destes AGs essenciais estão na terceira (n-3) ou sexta posição (n-6), a partir do hidrocarboneto final. Dentre os AGs $n-6$, encontram-se os ácidos linoléico (C18:2 n-6) e $\gamma$-linolênico (C18:3 n-6), que são precursores do ácido araquidônico (C20:4 n-6). Este último ácido é o primeiro componente da cascata de formação dos eicosanóides (WEITBERG, 1988; WILLIAMS; HIGGS, 1988; KINSELLA; BROUGHTON; WHELAN, 1990).

Dentre os ácidos graxos essenciais da família n-3, estão os ácidos $\alpha$-linolênico (C18:3), eicosapentaenóico (C20:5) e o docosa-hexaenóico (C22:6), que também podem ser precursores dos eicosanóides. As células animais podem apenas converter o ácido $\alpha$-linolênico em outros ácidos da mesma série n-3 como o eicosapentaenóico e o docosa-hexaenóico. Da mesma forma, o $\gamma$-linolênico e di-homo- $\gamma$-linolênico (20:3, n-6) podem se converter em ácido araquidônico da mesma série n-6. Sendo assim, AGs de séries diferentes não se interconvertem. Os ácidos graxos essenciais sofrem apenas processos de elongação com adição de novos átomos de carbono no grupo carboxílico final.

\subsection{1 Ácidos graxos e a função imunitária}


O desenvolvimento, manutenção e funcionalidade do sistema imune dependem de uma nutrição balanceada e adequada. Além da dieta, os AGs podem ser sintetizados a partir de outros nutrientes tais como glicose e aminoácidos. Os lipídios formados em linfócitos e macrófagos a partir de glicose e glutamina não são apenas importantes componentes estruturais, mas também são ativamente exportados para o meio extracelular (DE BITTENCOURT; CURI, 1997). Além disso, existem evidências de que os lipídios podem ser transferidos (especialmente ácidos graxos, fosfolipídios e colesterol) entre as células do sistema imune (DE BITTENCOURT; CURI, 1997).

Os AGs protonados atravessam a membrana rapidamente por difusão simples ou mediada pela criação de um gradiente de concentração promovido por proteínas citoplasmáticas tais como FABPs, "fatty acid-binding proteins", que se ligam aos ácidos graxos (SCHWIETERMAN et al., 1988). As FABPs também participam do transporte intracelular de ácidos graxos.

A membrana plasmática de leucócitos, como outras membranas biológicas, é composta de matrix de fluído lipídico. Os AGs têm função importante na estrutura da membrana, podendo influenciar diversas funções celulares. A composição dos fosfolípidios na membrana da célula pode ser alterada com o ciclo celular, idade, respostas a determinados estímulos ou devido a alterações na dieta. Essas alterações podem resultar em modificação na função celular (CALDER, 1997). Quanto mais insaturados os AGs que compõem a membrana celular maior é a fluidez da membrana. Estas alterações da fluidez podem afetar a interação celular, expressão de receptores, transporte de nutrientes e transmissão de sinais (KELLEY, 2001).

Os AGs estão envolvidos em processos de inflamação como quimiotaxia, adesão celular, diapedese e ativação de leucócitos (GORJAO et al., 2006). Além disso, os ácidos graxos modulam a função dos linfócitos, controlando a proliferação, produção de citocinas e eicosanóides, adesão celular, metabolismo e morte celular (POMPEIA et al., 2000). O tratamento das células com os AGs altera a funcionalidade de linfócitos. Otton et al. (1998) observaram inibição da proliferação de linfócitos em ratos alimentados com dietas ricas em lipídios (OTTON et al., 1998). 


\subsection{2 Ácidos palmítico e esteárico}

Os ácidos palmítico (16:0-PA) e esteárico (18:0-SA) são saturados de cadeia longa e abundantes na circulação. A concentração destes AGs na circulação está ainda mais elevada em indivíduos obesos e que apresentam diabetes do tipo 2 que está associada a hiperlipidemia e hiperglicemia (LU et al., 2003). Os ácidos palmítico e esteárico são liberados pelos linfócitos $T$ citotóxicos quando são ativados contribuindo para a indução de apoptose nas células alvo (RICHIERI; KLEINFELD, 1991; OBEID et al., 1993; PAUMEN et al., 1997).

Stentz e Kitabchi (2006) mostraram que o PA em concentrações de 50 e $500 \mu \mathrm{M}$ promove ativação de linfócitos $\mathrm{T}$ e de células endoteliais estimulando a externalização do receptor de insulina, da expressão de GLUT4, geração de espécies reativas de oxigênio, citocinas e IRS-1 (STENTZ; KITABCHI, 2006).

Nos estudos realizados em células endoteliais vasculares de humanos foi mostrado que o SA promove aumento da porcentagem de células na fase $G_{0} / G_{1}$ do ciclo celular e diminuição das células na fase $S$ caracterizando o seu efeito antiproliferativo (ARTWOHL et al., 2004).

\subsection{3 Ácido oléico}

O ácido oléico (18:1, n-9) $(O A)$ é um ácido graxo monoinsaturado não essencial, abundante na dieta, e importante substrato energético em linfócitos (ANEL et al., 1990). Este ácido graxo é considerado um dos fatores responsáveis pelos efeitos benéficos da dieta das populações mediterrâneas que são abundantes em óleo de oliva. Esta dieta apresenta efeito protetor em doenças coronarianas e câncer (TOKUDOME et al., 2000). O OA tem sido descrito como modulador da resposta imune, capaz de diminuir a incidência de artrite reumatóide e a sintomatologia típica de anormalidades autoimunes (DE PABLO; ALVAREZ DE CIENFUEGOS, 2000). Uma dieta rica em ácidos graxos monoinsaturados pode ter ação supressora na proliferação de linfócitos, atividade das células natural killer, adesão de leucócitos, monócitos e macrófagos causando inibição de TNF- $\alpha$ (JEFFERY; NEWSHOLME; CALDER, 
1997; YAQOOB, 1998; DE PABLO; ALVAREZ DE CIENFUEGOS, 2000). Redução da produção de citocinas como IL-2, IL-6, IL-8 e IL-10 em monócitos ocorre pela suplementação do ácido oléico na dieta de ratos (CALDER, 1998; POMPEIA et al., 2000).

\subsection{4 Ácido linoléico}

$O$ ácido linoléico (C18:2 n-6) (LA) é um ácido graxo poliinsaturado (AGPI) essencial e corresponde a $84-89 \%$ dos AGPIs totais da dieta. O LA é um ácido graxo de 18 carbonos com duas insaturações e da série $n-6$. A média do consumo de LA nos Estados Unidos e Norte da Europa correspondia a aproximadamente 3\% da ingestão calórica total em 1950, passando para 6 a 7\% em 1994 (11 a $16 \mathrm{~g} / \mathrm{dia}$ ), concomitantemente com o decréscimo do consumo de ácidos graxos saturados e AGPI n-3 (KRIS-ETHERTON et al., 2000; SIMOPOULOS, 2002). Entretanto, de 1986 para 1996 houve um decréscimo no consumo de óleo de soja de $87.7 \%$ para $76.4 \%$, concomitantemente com o aumento do consumo de outros óleos vegetais como o óleo de canola e milho.

Os AGPIs n-6 podem agir em células Jurkat (linhagem leucêmica de linfócitos T) suprimindo a produção da interleucina-2 (IL-2) por alteração de sinais de transdução e inativação dos genes de citocinas (WILLIAMS; ROSENBAUM; ZURIER, 1996). Os AGs n-6 têm propriedades pró-inflamatórias (HARBIGE, 1998). Há evidências de que dietas ricas em LA aumentam a expressão de ICAM-1 (YOUNG et al., 1998), a atividade de células natural killer (POMPEIA et al., 2000), produção de IgE por linfócitos, produção de IL-1, IL-6 e IL-8 em leucócitos (HARBIGE, 1998; YOUNG et al., 1998) e alteram a produção de superóxido e peróxido de hidrogênio em neutrófilos (LOPES et al., 1999).

Muitas das condições crônicas como diabetes, câncer, obesidade, doenças autoimunes, artrite reumatóide e asma estão associadas com 0 aumento na produção de leucotrienos $B_{4}\left(\right.$ LTB $\left._{4}\right)$, interleucina 1- $\beta$ (IL1- $\beta$ ), IL-6 e fator de necrose tumoral- $\alpha$ (TNF- $\alpha$ ) (SIMOPOULOS, 2002). O excesso do consumo de LA causa aumento na produção de prostaglandina $\mathrm{E}_{2}\left(\mathrm{PGE}_{2}\right)$. Este 
aumento pode estar associado ao risco de trombose em situações pósoperatórias (ROULET et al., 1997).

\subsection{5 Ácidos docosa-hexaenóico (DHA) e eicosapentaenóico (EPA)}

Os AGs docosa-hexaenóico (22:6) (DHA) e eicosapentaenóico (20:5) (EPA) pertencem aos AGs essenciais da série n-3 e também são precursores de eicosanóides biologicamente menos ativos, como as prostaglandinas da série 3 e leucotrienos da série 6 . Vários autores descreveram os efeitos benéficos dos ácidos graxos $n-3$ nas doenças autoimunes, principalmente 0 ácido eicosapentaenóico (EPA). Os ácidos graxos poliinsaturados n-3 atuam como agentes antiinflamatórios e atenuam os efeitos promovidos pela reação inflamatória exacerbada sendo caracterizados como imunossupressores (HUGHES et al., 1995; CALDER, 2003). Suplementação de humanos e animais com óleo de peixe, que é uma fonte rica em AGs n-3, promove diminuição da produção de IL-2 e da proliferação de linfócitos $T$ indicando ser este um agente depressor das funções imunes mediadas por células T (JOLLY; MCMURRAY; CHAPKIN, 1998; ENDRES et al., 1989; MOLVIG et al., 1991; SADEGHI; WALLACE; CALDER, 1999; THIES et al., 2001). Pacientes com artrite reumatóide, psoríasis e lupus eritematoso suplementados com óleo de peixe rico em EPA apresentaram melhora devido à diminuição da função de células do sistema imune (SOYLAND; DREVON, 1993; HUGHES et al., 1995).

Embora os efeitos destes dois AGs sejam generalizados em grande parte dos estudos, nos últimos seis anos foram demonstradas diferenças quando os experimentos foram realizados com DHA e EPA isoladamente. Hung et al. (1999) compararam o efeito de duas preparações de óleo de peixe contendo diferentes concentrações dos ácidos EPA e DHA na produção de imunoglobulinas em linfócitos. Os autores observaram que o EPA tem uma atividade antialérgica maior que o DHA. O EPA é mais efetivo na supressão da resposta imune em relação ao DHA (SASAKI et al., 1999; VOLKER; FITZGERALD; GARG, 2000). Verlengia et al., 2004 observaram que EPA e DHA modulam a expressão de genes diferentes em linfócitos $B$ e $T$ em cultura. 
Suplementações com óleo de peixe contendo diferentes proporções de EPA e DHA podem exrcer efeitos divergentes sobre as células do sistema imune. Kew et al. (2004) suplementaram um grupo de voluntários saudáveis com óleo de peixe rico em EPA (4,7 g por dia) e outro rico em DHA (4,9 g por dia). Os autores observaram que a suplementação com DHA, mas não com EPA, suprimiu a ativação de linfócitos $T$, pois promoveu diminuição da expressão de CD69 (KEW et al., 2004). Em contraposição, em estudos realizados por nosso grupo, observou-se que a suplementação com uma menor quantidade de óleo de peixe rico em DHA (1,62 g por dia) promove aumento da capacidade proliferativa de linfócitos (GORJAO et al., 2006). Ambos os estudos, além de mostrarem que os AGs interferem na função de linfócitos, são indicativos de que diferentes concentrações destes AGs podem atuar de maneiras opostas nestas células.

\subsection{Mecanismos de ação dos AGs na sinalização intracelular}

Os AGPI controlam a resposta imune diretamente, regulando fatores transcricionais e indiretamente promovendo alteração na composição lipídica da membrana celular, resultando em modificações na produção de segundos mensageiros e, assim, permitindo mudanças na expressão gênica (FERNANDES; TROYER; JOLLY, 1998; KELLEY, 2001). Os AGs n-3 incorporados nos fosfolipídios de membrana podem afetar a sinalização celular através da produção de diacilglicerol (DAG) após a hidrólise fosfolipídica. Nas células $T$, o DAG é produzido de forma bifásica. A produção de DAG ocorre pela hidrólise de fosfatidilinositol 4,5 bisfosfato $\left(\mathrm{PIP}_{2}\right)$ catalisada pela fosfolipase C (PLC). A segunda fase da produção de DAG está associada com a ativação da fosfolipase $D$ (PLD) catalisada pela hidrólise de fosfatildilcolina $(P C)$, produzindo ácido fosfatídico, que pode ser convertido em DAG pela ação da fosfo-hidrolase de fosfatidato (SEBALDT; ADAMS; UHING, 1992; KHAN; HICHAMI, 1999). Nos estudos desenvolvidos em cardiomiócitos, a incorporação de DHA no DAG modula a contratilidade celular (BORDONI et al., 1992). Já a incorporação de EPA no DAG promoveu redução de complicações vasculares associadas com diabetes (KUROKI et al., 1998). As isoformas de 
PKC diferem na sua atividade em resposta aos diferentes conteúdos de AGs n6 e n-3 (MADANI et al., 2001).

Em células endoteliais de veia de cordão umbilical, a fosforilação de ERK 1/2 é importante para impedir a ativação destas células contrapondo-se às ações pró-inflamatórias das vias da p38 e JNK. EPA e DHA (20 $\mu \mathrm{M})$ acentuaram o aumento da fosforilação de ERK 1/2 nestas células contrapondose ao efeito do TNF- $\alpha$ que induz desativação destas proteínas (XUE et al., 2006). Por outro lado, em estudos de Denys et al. $(2001,2002)$ foi mostrado que tanto EPA quanto DHA promovem diminuição da atividade de ERK 1/2 em células Jurkat estimuladas com PMA ou com anticorpos anti-CD3. O DHA promoveu diminuição da atividade de ERK1/2 em concentrações menores que o EPA. Além disso, também foi observada diminuição da translocação da PKC $\alpha$ e $\varepsilon$ para a membrana das células tratadas com estes AGs, mostrando que o possível mecanismo pela qual estes AGs inibem a ativação de ERK1/2 em linfócitos ativados pode ocorrer por inibição da translocação da PKC (DENYS; HICHAMI; KHAN, 2005). Entretanto, estes AGs também podem inibir a fosforilação de MAP quinase por via independente da PKC, uma vez que estes inibem a fosforilação induzida por anticorpos anti-CD3 que atuam por mecanismos independentes da PKC (DENYS; HICHAMI; KHAN, 2002).

A enzima ERK2 pode fosforilar os resíduos de serina de STAT 5 podendo alterar a sua atividade transcricional. Visto que os AGs modulam a atividade de ERK1/2, podem também alterar a atividade de outras proteínas como STAT.

Dietas ricas em ácidos graxos n-3 alteram a composição lipídica dos lipid rafts e reduzem o conteúdo de esfingolipídios nestes microdomínios (FAN et al., 2003). Estes dados podem explicar em parte algumas das alterações promovidas por estes AGs na sinalização destas células uma vez que os TCRs estão compartimentalizados nestes microdomínios, como descrito anteriormente. Fan et al. (2004) nos estudos realizados em camundongos alimentados com óleo de peixe e com DHA purificado observaram redução da co-localização de PKC $\theta$ com os lipid rafts (FAN et al., 2004). Neste mesmo estudo, a alimentação com óleo de peixe promoveu diminuição da atividade transcricional de AP1 e NF-кB e conseqüentemente da 
secreção de IL-2. Resultados semelhantes foram observados por Denys et al. (2005) que avaliaram os efeitos dos ácidos graxos EPA e DHA em células Jurkat (linfócitos T). Neste estudo foi observada inibição da ativação de NF-kB por ambos os AGs após estimulação com PMA. Este efeito inibitório foi revertido quando as células foram tratadas com inibidores das duas isoformas de $\mathrm{PLA}_{2}$ (cálcio dependente e cálcio independente) implicadas na liberação de DHA e EPA, respectivamente.

Larbi et al. (2005), nos estudos em indivíduos saudáveis que receberam uma emulsão lipídica rica em ácido linoléico por via parenteral, observaram alterações na distribuição de lipid rafts na membrana celular de linfócitos (LARBI et al., 2005). Neste mesmo estudo observou-se diminuição da fosforilação total de tirosina, da fosforilação de LAT e de Akt. Já a fosforilação de ERK 1/2 e p38 não foi alterada pela emulsão rica em ácido linoléico. $O$ enriquecimento dos lipid rafts com cadeias linoleil promoveu desarranjo de proteínas impedindo a interação de LAT com TCR e consequentemente a sua fosforilação.

Os AGs podem modular a função de diversas células do sistema imune, inclusive de linfócitos. O estabelecimento da toxicidade dos AGs mais abundantes na circulação (PA e SA), na dieta ocidental (OA e LA) e daqueles utilizados na terapêutica é importante para o desenvolvimento de estudos mais específicos sobre a ação destes AGs. Além disso, a descrição dos mecanismos exatos pelos quais estes AGs podem inibir ou ativar a função de linfócitos é essencial para que se possa utilizá-los como ferramenta para o estudo ou tratamento de diversas patologias relacionadas ao sistema imunológico.

Desta forma, no presente estudo avaliamos: a toxicidade dos AGs sobre linfócitos humanos in vitro, os efeitos de diferentes concentrações destes sobre a capacidade proliferativa destas células e a ação destes AGs sobre as vias de sinalização intracelulares ativadas pela IL-2, a principal citocina que induz a ativação total de linfócitos T. Além isso, outras vias alternativas como ativação de PKC, alteração da distribuição de lipid rafts e atividade total de fosfatases foram avaliadas. 


\section{CONCLUSÕES}

Concentrações crescentes de ácidos graxos induzem apoptose em linfócitos humanos. EPA, DHA, PA e SA diminuíram a proliferação celular e a progressão do ciclo celular em concentrações não tóxicas caracterizando o efeito imunossupressor destes AGs. Por outro lado, OA e LA exerceram efeito oposto sobre a ativação destas células em baixas concentrações, pois causaram aumento da capacidade proliferativa de linfócitos em 12,5 e $25 \mu \mathrm{M}$ caracterizando um efeito imunoestimulatório. Estes dois AGs também acentuaram o efeito estimulatório da IL-2 sobre a proliferação de linfócitos enquanto que EPA, DHA, PA e SA inibiram este efeito.

Com relação aos mecanismos pelos quais estes AGs alteram a funcionalidade de linfócitos concluímos que o efeito inibitório dos ácidos PA, SA e DHA na proliferação de linfócitos está associado a uma redução da fosforilação de proteínas estimulada pela IL-2 como JAK/STAT, ERK1/2 e Akt que ocorreu devido à diminuição da expressão de CD25 na membrana plasmática. Este deslocamento de CD25 promovido pelo DHA está relacionado a uma alteração da distribuição dos lipid rafts na membrana que não foi observada pelo tratamento com os outros AGs. A diminuição da proliferação promovida por EPA também está relacionada com a inibição da fosforilação de proteínas da via da IL-2, mas que não envolve alteração da expressão de CD25 na superfície da membrana plasmática. Por outro lado, OA e LA estimularam a proliferação de linfócitos aumentando a fosforilação de ERK1/2 através da ativação da PKC- $\zeta$ que é uma via independente de JAK/STAT.

Os resultados são sugestivos de que os AGs estudados podem alterar a função de linfócitos através da modulação das vias de sinalização ativadas pela IL-2 que é a principal citocina estimulatória para estas células. 


\section{REFERÊNCIAS ${ }^{*}$}

AGHAZADEH, B. et al. Structural Basis for Relief of Autoinhibition of the Dbl Homology Domain of Proto-Oncogene Vav by Tyrosine Phosphorylation. Cell, v.102, n.5, p.625-33, 2000.

ANEL, A. et al. Fatty Acid Metabolism in Human Lymphocytes. I. Time-Course Changes in Fatty Acid Composition and Membrane Fluidity During Blastic Transformation of Peripheral Blood Lymphocytes. Biochim. Biophys. Acta, v.1044, n.3, p.323-31, 1990.

ARINGER, M. T Lymphocyte Activation--an inside Overview. Acta Med. Austriaca, v.29, n.1, p.7-13, 2002.

ARPAIA, E. et al. Defective T Cell Receptor Signaling and Cd8+ Thymic Selection in Humans Lacking Zap-70 Kinase. Cell, v.76, n.5, p.947-58, 1994.

ARTWOHL, M. et al. Free Fatty Acids Trigger Apoptosis and Inhibit Cell Cycle Progression in Human Vascular Endothelial Cells. Faseb J., v.18, n.1, p.146-8, 2004.

AUGUSTINE, J. A. et al. Interleukin 2- and Polyomavirus Middle T AntigenInduced Modification of Phosphatidylinositol 3-Kinase Activity in Activated T Lymphocytes. Mol. Cell Biol., v.11, n.9, p.4431-40, 1991.

BALAMUTH, F. et al. Cd4 Raft Association and Signaling Regulate Molecular Clustering at the Immunological Synapse Site. J. Immunol., v.172, n.10, p.5887-92, 2004.

BEADLING, C. et al. Interleukin-2 Activation of Stat5 Requires the Convergent Action of Tyrosine Kinases and a Serine/Threonine Kinase Pathway Distinct from the Raf1/Erk2 Map Kinase Pathway. EMBO J., v.15, n.8, p.1902-13, 1996.

BERRA, E. et al. Protein Kinase C Zeta Isoform Is Critical for Mitogenic Signal Transduction. Cell, v.74, n.3, p.555-63, 1993.

BHAT, N. R.; ZHANG, P. Activation of Mitogen-Activated Protein Kinases in Oligodendrocytes. J. Neurochem., v.66, n.5, p.1986-94, 1996.

BOKOCH, G. M.; DER, C. J. Emerging Concepts in the Ras Superfamily of GtpBinding Proteins. Faseb J., v.7, n.9, p.750-9, 1993.

\footnotetext{
* De acordo com:

ASSOCIAÇÃO BRASILEIRA DE NORMAS TÉCNICAS. NBR 6023: Informação e documentação: referências: elaboração. Rio de Janeiro, 2002.
} 
BORDONI, A. et al. Correlation between the Acidic Composition of Diacylglycerol and Protein Kinase $C$ Activation in Cultures of Rat Cardiomyocytes]. Cardiologia, v.37, n.9, p.631-4, 1992.

BOULTON, T. G. et al. Erks: A Family of Protein-Serine/Threonine Kinases That Are Activated and Tyrosine Phosphorylated in Response to Insulin and Ngf. Cell, v.65, n.4, p.663-75, 1991.

BRADFORD, M. M. A Rapid and Sensitive Method for the Quantitation of Microgram Quantities of Protein Utilizing the Principle of Protein-Dye Binding. Anal. Biochem., v.72, p.248-54, 1976.

BRDICKA, T. et al. T Cell Receptor Signalling Results in Rapid Tyrosine Phosphorylation of the Linker Protein Lat Present in Detergent-Resistant Membrane Microdomains. Biochem. Biophys. Res. Commun., v.248, n.2, p.356-60, 1998.

BUTTKE, T. M.; CUCHENS, M. A. Inhibition of Lymphocyte Proliferation by Free Fatty Acids. II. Toxicity of Stearic Acid Towards PhytohaemagglutininActivated T Cells. Immunology, v.53, n.3, p.507-14, 1984.

CALDER, P. C. N-3 Polyunsaturated Fatty Acids and Immune Cell Function. Adv. Enzyme Regul., v.37, p.197-237, 1997.

CALDER, P. C. Dietary Fatty Acids and Lymphocyte Functions. Proc. Nutr. Soc., v.57, n.4, p.487-502, 1998.

CALDER, P. C. Long-Chain N-3 Fatty Acids and Inflammation: Potential Application in Surgical and Trauma Patients. Braz. J. Med. Biol. Res., v.36, n.4, p.433-46, 2003.

CHAMBERS, C. A.; ALLISON, J. P. Costimulatory Regulation of T Cell Function. Curr. Opin. Cell Biol., v.11, n.2, p.203-10, 1999.

CHAN, A. C. et al. The Role of Protein Tyrosine Kinases and Protein Tyrosine Phosphatases in T Cell Antigen Receptor Signal Transduction. Annu. Rev. Immunol., v.12, p.555-92, 1994.

CHAN, E. Y. et al. Expression of IL-2r, IL-4r, IL-6r on Peripheral Blood Lymphocytes in Systemic Lupus Erythematosus and Correlation with Disease Activity: A Prospective Study. J. Clin. Pathol., v.49, n.8, p.660-3, 1996.

CHARDIN, P. et al. Human Sos1: A Guanine Nucleotide Exchange Factor for Ras That Binds to Grb2. Science, v.260, n.5112, p.1338-43, 1993.

CHIU, L. C. et al. Docosahexaenoic Acid Modulates Different Genes in Cell Cycle and Apoptosis to Control Growth of Human Leukemia HI-60 Cells. Int. J. Oncol., v.25, n.3, p.737-44, 2004. 
CHUNG, J. et al. Stat3 Serine Phosphorylation by Erk-Dependent and Independent Pathways Negatively Modulates Its Tyrosine Phosphorylation. Mol. Cell Biol., v.17, n.11, p.6508-16, 1997.

COHEN, P. The Role of Protein Phosphorylation in Neural and Hormonal Control of Cellular Activity. Nature, v.296, n.5858, p.613-20, 1982.

COSTELLO, P. S. et al. The Rho-Family Gtp Exchange Factor Vav Is a Critical Transducer of $T$ Cell Receptor Signals to the Calcium, Erk, and Nf-Kappab Pathways. Proc. Natl. Acad. Sci. U.S.A., v.96, n.6, p.3035-40, 1999.

CURY-BOAVENTURA, M. F. et al. Toxicity of a Soybean Oil Emulsion on Human Lymphocytes and Neutrophils. JPEN J. Parenter. Enteral. Nutr., v.30, n.2, p.115-23, 2006.

DARNELL, J. E., JR. Studies of Ifn-Induced Transcriptional Activation Uncover the Jak-Stat Pathway. J. Interferon Cytokine Res., v.18, n.8, p.549-54, 1998.

DATTA, S. R. et al. Cellular Survival: A Play in Three Akts. Genes Dev., v.13, n.22, p.2905-27, 1999.

DAVID, M. et al. Requirement for Map Kinase (Erk2) Activity in Interferon Alphaand Interferon Beta-Stimulated Gene Expression through Stat Proteins. Science, v.269, n.5231, p.1721-3, 1995.

DE BITTENCOURT, P. I., JR.; CURI, R. Macrophages Transfer Cholesterol to Lymphocytes in Culture. Biochem. Soc. Trans., v.25, n.2, p.345S, 1997.

DE PABLO, M. A.; ALVAREZ DE CIENFUEGOS, G. Modulatory Effects of Dietary Lipids on Immune System Functions. Immunol. Cell Biol., v.78, n.1, p.31-9, 2000.

DENYS, A. et al. Eicosapentaenoic Acid and Docosahexaenoic Acid Modulate Map Kinase (Erk1/Erk2) Signaling in Human T Cells. J. Lipid Res., v.42, n.12, p.2015-20, 2001.

DENYS, A. et al. Eicosapentaenoic Acid and Docosahexaenoic Acid Modulate Map Kinase Enzyme Activity in Human T-Cells. Mol. Cell Biochem., v.232, n.12, p.143-8, 2002.

DENYS, A. et al. N-3 Pufas Modulate T-Cell Activation Via Protein Kinase CAlpha and -Epsilon and the Nf-Kappab Signaling Pathway. J. Lipid Res., v.46, n.4, p.752-8, 2005.

DINERSTEIN-CALI, H. et al. Growth Hormone (Gh) Induces the Formation of Protein Complexes Involving Stat5, Erk2, Shc and Serine Phosphorylated Proteins. Mol. Cell Endocrinol., v.166, n.2, p.89-99, 2000. 
DONATO, N. J.; PEREZ, M. Tumor Necrosis Factor-Induced Apoptosis Stimulates P53 Accumulation and P21waf1 Proteolysis in Me-180 Cells. J. Biol. Chem., v.273, n.9, p.5067-72, 1998.

DORSCH, M. et al. Gene Transfer of the Interleukin (II)-2 Receptor Beta Chain into an II-7-Dependent Pre-B Cell Line Permits II-2-Driven Proliferation: Tyrosine Phosphorylation of Shc Is Induced by IL-2 but Not II-7. Eur. J. Immunol., v.24, n.9, p.2049-54, 1994.

DU, K.; TSICHLIS, P. N. Regulation of the Akt Kinase by Interacting Proteins. Oncogene, v.24, n.50, p.7401-9, 2005.

DUTIL, E. M. et al. In Vivo Regulation of Protein Kinase C by TransPhosphorylation Followed by Autophosphorylation. J. Biol. Chem., v.269, n.47, p.29359-62, 1994.

DWYER, J. M.; JOHNSON, C. The Use of Concanavalin a to Study the Immunoregulation of Human T Cells. Clin. Exp. Immunol., v.46, n.2, p.237-49, 1981.

ELLERY, J. M.; NICHOLLS, P. J. Alternate Signalling Pathways from the Interleukin-2 Receptor. Cytokine Growth Factor Rev., v.13, n.1, p.27-40, 2002.

ENDRES, S. et al. The Effect of Dietary Supplementation with $\mathrm{N}-3$ Polyunsaturated Fatty Acids on the Synthesis of Interleukin-1 and Tumor Necrosis Factor by Mononuclear Cells. N. Engl. J. Med., v.320, n.5, p.265-71, 1989.

FALK, M. et al. Caspase Inhibition Blocks Human $\mathrm{T}$ Cell Proliferation by Suppressing Appropriate Regulation of II-2, Cd25, and Cell Cycle-Associated Proteins. J. Immunol., v.173, n.8, p.5077-85, 2004.

FAN, W. H.; KARNOVSKY, M. J. Activation of Protein Kinase C Inhibits the Expression of Connective Tissue Growth Factor. Biochem. Biophys. Res. Commun., v.275, n.2, p.312-21, 2000.

FAN, Y. Y. et al. Dietary Docosahexaenoic Acid Suppresses T Cell Protein Kinase C Theta Lipid Raft Recruitment and II-2 Production. J. Immunol., v.173, n.10, p.6151-60, 2004.

FAN, Y. Y. et al. Dietary (N-3) Polyunsaturated Fatty Acids Remodel Mouse TCell Lipid Rafts. J. Nutr., v.133, n.6, p.1913-20, 2003.

FERNANDES, G. et al. The Effects of Dietary Lipids on Gene Expression and Apoptosis. Proc. Nutr. Soc., v.57, n.4, p.543-50, 1998.

FERNANDEZ-GUTIERREZ, B. et al. Characterization and Regulation of Cd69 Expression on Rheumatoid Arthritis Synovial Fluid T Cells. J. Rheumatol., v.22, n.3, p.413-20, 1995. 
FILACI, G. et al. Is There a Role for Nk Cells in the Pathogenesis of Multiple Sclerosis? A Case Study. Hum. Immunol., v.60, n.3, p.231-8, 1999.

FINCO, T. S. et al. Lat Is Required for Tcr-Mediated Activation of Plcgamma1 and the Ras Pathway. Immunity, v.9, n.5, p.617-26, 1998.

FINSTAD, H. S. et al. Uptake and Activation of Eicosapentaenoic Acid Are Related to Accumulation of Triacylglycerol in Ramos Cells Dying from Apoptosis. J. Lipid Res., v.41, n.4, p.554-63, 2000.

FOTI, M. et al. P56lck Anchors Cd4 to Distinct Microdomains on Microvilli. Proc. Natl. Acad. Sci. U.S.A., v.99, n.4, p.2008-13, 2002.

FRAGOSO, R. et al. Lipid Raft Distribution of Cd4 Depends on Its Palmitoylation and Association with Lck, and Evidence for Cd4-Induced Lipid Raft Aggregation as an Additional Mechanism to Enhance Cd3 Signaling. J. Immunol., v.170, n.2, p.913-21, 2003.

FREIRE, A. C. et al. Relationship between Phosphatase Activity and Cytotoxic Effect of Two Protein Phosphatase Inhibitors, Okadaic Acid and Pervanadate, on Human Myeloid Leukemia Cell Line. J. Enzyme Inhib. Med. Chem., v.18, n.5, p.425-9, 2003.

FUJII, H. et al. Activation of Stat5 by Interleukin 2 Requires a Carboxyl-Terminal Region of the Interleukin 2 Receptor Beta Chain but Is Not Essential for the Proliferative Signal Transmission. Proc. Natl. Acad. Sci. U.S.A., v.92, n.12, p.5482-6, 1995.

GAFFEN, S. L. et al. Signaling through the Interleukin 2 Receptor Beta Chain Activates a Stat-5-Like DNA-Binding Activity. Proc. Natl. Acad. Sci. U.S.A., v.92, n.16, p.7192-6, 1995.

GELAS, P. et al. Effect of Parenteral Medium- and Long-Chain Triglycerides on Lymphocytes Subpopulations and Functions in Patients with Acquired Immunodeficiency Syndrome: A Prospective Study. JPEN J. Parenter. Enteral Nutr., v.22, n.2, p.67-71, 1998.

GENOT, E.; CANTRELL, D. A. Ras Regulation and Function in Lymphocytes. Curr. Opin. Immunol., v.12, n.3, p.289-94, 2000.

GORJAO, R. et al. Effect of Docosahexaenoic Acid-Rich Fish Oil Supplementation on Human Leukocyte Function. Clin. Nutr., v.25, n.6, p.92338, 2006.

GOTOH, N. et al. A Novel Pathway from Phosphorylation of Tyrosine Residues 239/240 of Shc, Contributing to Suppress Apoptosis by II-3. EMBO J., v.15, n.22, p.6197-204, 1996. 
GRANATO, D. et al. Effects of Parenteral Lipid Emulsions with Different Fatty Acid Composition on Immune Cell Functions in Vitro. JPEN J. Parenter. Enteral Nutr., v.24, n.2, p.113-8, 2000.

GRAVES, J. D. et al. The Growth Factor II-2 Activates P21ras Proteins in Normal Human T Lymphocytes. J. Immunol., v.148, n.8, p.2417-22, 1992.

GREENFIELD, E. A. et al. Cd28/B7 Costimulation: A Review. Crit. Rev. Immunol., v.18, n.5, p.389-418, 1998.

GU, H. et al. New Role for Shc in Activation of the Phosphatidylinositol 3Kinase/Akt Pathway. Mol. Cell Biol., v.20, n.19, p.7109-20, 2000.

HARBIGE, L. S. Dietary N-6 and N-3 Fatty Acids in Immunity and Autoimmune Disease. Proc. Nutr. Soc., v.57, n.4, p.555-62, 1998.

HARRISON, L. E. et al. Butyrate-Induced G2/M Block in Caco-2 Colon Cancer Cells Is Associated with Decreased P34cdc2 Activity. Proc. Soc. Exp. Biol. Med., v.222, n.2, p.150-6, 1999.

HASPEL, R. L.; DARNELL, J. E., JR. A Nuclear Protein Tyrosine Phosphatase Is Required for the Inactivation of Stat1. Proc. Natl. Acad. Sci. U.S.A., v.96, n.18, p.10188-93, 1999.

HATAKEYAMA, M. et al. A Restricted Cytoplasmic Region of II-2 Receptor Beta Chain Is Essential for Growth Signal Transduction but Not for Ligand Binding and Internalization. Cell, v.59, n.5, p.837-45, 1989.

HEALY, D. A. et al. Polyunsaturated and Monounsaturated Fatty Acids Increase Neutral Lipid Accumulation, Caspase Activation and Apoptosis in a NeutrophilLike, Differentiated HI-60 Cell Line. Clin. Sci., v.104, n.2, p.171-9, 2003.

HETZ, C. A. et al. Caspase-Dependent Initiation of Apoptosis and Necrosis by the Fas Receptor in Lymphoid Cells: Onset of Necrosis Is Associated with Delayed Ceramide Increase. J. Cell Sci., v.115, n.Pt 23, p.4671-83, 2002.

HIROSE, T. et al. Hla-Dr, Dq and Dp Antigen Expression in Synovial Fluid T Lymphocytes in Rheumatoid Arthritis: Cell Cycle Analysis of Hla-Dp Positive T Cells. J. Rheumatol., v.17, n.1, p.18-23, 1990.

HUGHES, D. A. et al. N-3 Polyunsaturated Fatty Acids (Pufa) Modulate the Expression of Functionally Associated Molecules on Human Monocytes. Biochem. Soc. Trans., v.23, n.2, p.303S, 1995.

HUNG, P. et al. Dietary Effect of Epa-Rich and Dha-Rich Fish Oils on the Immune Function of Sprague-Dawley Rats. Biosci. Biotechnol. Biochem., v.63, n.1, p.135-40, 1999.

IZQUIERDO PASTOR, M. et al. The Regulation and Function of P21ras During T-Cell Activation and Growth. Immunol. Today, v.16, n.3, p.159-64, 1995. 
JANES, P. W. et al. Aggregation of Lipid Rafts Accompanies Signaling Via the T Cell Antigen Receptor. J. Cell Biol., v.147, n.2, p.447-61, 1999.

JEFFERY, N. M. et al. Level of Polyunsaturated Fatty Acids and the N-6 to N-3 Polyunsaturated Fatty Acid Ratio in the Rat Diet Alter Serum Lipid Levels and Lymphocyte Functions. Prostaglandins Leukot. Essent. Fatty Acids, v.57, n.2, p.149-60, 1997.

JIA, Z. Protein Phosphatases: Structures and Implications. Biochem. Cell Biol., v.75, n.1, p.17-26, 1997.

JOLLY, C. A. et al. Effect of Dietary N-3 Fatty Acids on Interleukin-2 and Interleukin-2 Receptor Alpha Expression in Activated Murine Lymphocytes. Prostaglandins Leukot. Essent Fatty Acids, v.58, n.4, p.289-93, 1998.

JULIUS, U. Influence of Plasma Free Fatty Acids on Lipoprotein Synthesis and Diabetic Dyslipidemia. Exp. Clin. Endocrinol. Diabetes, v.111, n.5, p.246-50, 2003.

KABOURIDIS, P. S. et al. S-Acylation of Lck Protein Tyrosine Kinase Is Essential for Its Signalling Function in T Lymphocytes. Embo J., v.16, n.16, p.4983-98, 1997.

KACZMAREK, L. et al. Effect of Interleukin-2 on the Expression of Cell Cycle Genes in Human T Lymphocytes. Biochem. Biophys. Res. Commun., v.133, n.2, p.410-6, 1985.

KARNITZ, L. M. et al. Interleukin-2 Triggers a Novel Phosphatidylinositol 3Kinase-Dependent Mek Activation Pathway. Mol. Cell Biol., v.15, n.6, p.3049$57,1995$.

KELLEY, D. S. Modulation of Human Immune and Inflammatory Responses by Dietary Fatty Acids. Nutrition, v.17, n.7-8, p.669-73, 2001.

KERSH, E. N. et al. Fidelity of T Cell Activation through Multistep T Cell Receptor Zeta Phosphorylation. Science, v.281, n.5376, p.572-5, 1998.

KEW, S. et al. Effects of Oils Rich in Eicosapentaenoic and Docosahexaenoic Acids on Immune Cell Composition and Function in Healthy Humans. Am. J. Clin. Nutr., v.79, n.4, p.674-81, 2004.

KHAN, N. A.; HICHAMI, A. Ionotrophic 5-Hydroxytryptamine Type 3 Receptor Activates the Protein Kinase C-Dependent Phospholipase D Pathway in Human T-Cells. Biochem. J., v.344 Pt 1, p.199-204, 1999.

KHAN, N. A. et al. Docosahexaenoic Acid Inhibits Cancer Cell Growth Via P27kip1, Cdk2, Erk1/Erk2, and Retinoblastoma Phosphorylation. J. Lipid Res., v.47, n.10, p.2306-13, 2006. 
KHAN, W. A. et al. Selective Regulation of Protein Kinase C Isoenzymes by Oleic Acid in Human Platelets. J. Biol. Chem., v.268, n.7, p.5063-8, 1993.

KHOSHNAN, A. et al. The Nf-Kappa B Cascade Is Important in Bcl-XI Expression and for the Anti-Apoptotic Effects of the Cd28 Receptor in Primary Human Cd4+ Lymphocytes. J. Immunol., v.165, n.4, p.1743-54, 2000.

$\mathrm{KIM}$, H. J. et al. Docosahexaenoic Acid Induces Apoptosis in Proliferating Human Endothelial Cells. J. Cell Physiol., v.204, n.3, p.881-8, 2005.

KIM, T. K.; MANIATIS, T. Regulation of Interferon-Gamma-Activated Stat1 by the Ubiquitin-Proteasome Pathway. Science, v.273, n.5282, p.1717-9, 1996.

KIMURA, G. M. et al. Reduced Concanavalin a Capping of Neonatal Polymorphonuclear Leukocytes (Pmns). Pediatr. Res., v.15, n.9, p.1271-3, 1981.

KINSELLA, J. E. et al. Dietary Unsaturated Fatty Acids: Interactions and Possible Needs in Relation to Eicosanoid Synthesis. J. Nutr. Biochem., v.1, n.3, p.123-41, 1990.

KIRKEN, R. A. et al. Two Discrete Regions of Interleukin-2 (II2) Receptor Beta Independently Mediate II2 Activation of a Pd98059/Rapamycin/WortmanninInsensitive Stat5a/B Serine Kinase. J. Biol. Chem., v.272, n.24, p.15459-65, 1997.

KIRKEN, R. A. et al. Activation of Jak3, but Not Jak1, Is Critical for II-2-Induced Proliferation and Stat5 Recruitment by a Cooh-Terminal Region of the II-2 Receptor Beta-Chain. Cytokine, v.7, n.7, p.689-700, 1995.

KOBAYASHI, $M$. et al. Protein Kinase $C$ Activation by 12-0Tetradecanoylphorbol 13-Acetate in Cg-4 Line Oligodendrocytes Stimulates Turnover of Choline and Ethanolamine Phospholipids by Phospholipase D and Induces Rapid Process Contraction. J. Neurochem., v.76, n.2, p.361-71, 2001.

KOEGL, M. et al. Palmitoylation of Multiple Src-Family Kinases at a Homologous N-Terminal Motif. Biochem. J., v.303, p.749-53, 1994. Pt 3.

KOVANEN, P. E.; LEONARD, W. J. Inhibitors Keep Cytokines in Check. Curr. Biol., v.9, n.23, p.R899-902, 1999.

KRIS-ETHERTON, P. M. et al. Polyunsaturated Fatty Acids in the Food Chain in the United States. Am. J. Clin. Nutr., v.71, n.1, p.179S-88S, 2000. Suppl.

KUROKI, T. et al. Effect of Eicosapentaenoic Acid on Glucose-Induced Diacylglycerol Synthesis in Cultured Bovine Aortic Endothelial Cells. Biochem. Biophys. Res. Commun., v.247, n.2, p.473-7, 1998. 
LARBI, A. et al. Acute in Vivo Elevation of Intravascular Triacylglycerol Lipolysis Impairs Peripheral T Cell Activation in Humans. Am. J. Clin. Nutr., v.82, n.5, p.949-56, 2005.

LAW, C. L. et al. Regulation of Lymphocyte Activation by the Cell-Surface Molecule Cd22. Immunol. Today, v.15, n.9, p.442-9, 1994.

LEONARD, C. J. et al. The Role of P53 in Cell-Cycle Control and Apoptosis: Implications for Cancer. Important. Adv. Oncol., p.33-42, 1995.

LESTER, D. S. et al. Arachidonic Acid and Diacylglycerol Act Synergistically to Activate Protein Kinase $\mathrm{C}$ in Vitro and in Vivo. Biochem. Biophys. Res. Commun., v.179, n.3, p.1522-8, 1991.

LI, Q. et al. Polyunsaturated Eicosapentaenoic Acid Changes Lipid Composition in Lipid Rafts. Eur. J. Nutr., v.45, n.3, p.144-51, 2006.

LI, Q. et al. Docosahexaenoic Acid Changes Lipid Composition and Interleukin2 Receptor Signaling in Membrane Rafts. J. Lipid Res., v.46, n.9, p.1904-13, 2005.

LIMA, T. M. et al. Ranking the Toxicity of Fatty Acids on Jurkat and Raji Cells by Flow Cytometric Analysis. Toxicol. In Vitro, v.16, n.6, p.741-7, 2002.

LINDAHL, G. et al. Epithelial Hla-Dr Expression and T Lymphocyte Subsets in Salivary Glands in Sjogren's Syndrome. Clin. Exp. Immunol., v.61, n.3, p.47582, 1985.

LISTENBERGER, L. L. et al. Triglyceride Accumulation Protects against Fatty Acid-Induced Lipotoxicity. Proc. Natl. Acad. Sci. U.S.A., v.100, n.6, p.3077-82, 2003.

LIU, J. et al. Pdgf-Induced Glycosaminoglycan Synthesis Is Mediated Via Phosphatidylinositol 3-Kinase. Am. J. Physiol., v.274, n.5 Pt 1, p.L702-13, 1998.

LOPES, L. R. et al. NADPH-Oxidase Activity and Lipid Peroxidation in Neutrophils from Rats Fed Fat-Rich Diets. Cell Biochem. Funct., v.17, n.1, p.57-64, 1999.

LOPEZ-MARURE, R. et al. Ceramide Mimics Tumour Necrosis Factor-Alpha in the Induction of Cell Cycle Arrest in Endothelial Cells. Induction of the Tumour Suppressor P53 with Decrease in Retinoblastoma/Protein Levels. Eur. J. Biochem., v.267, n.14, p.4325-33, 2000.

LORD, J. D. et al. The II-2 Receptor Promotes Proliferation, Bcl-2 and Bcl-X Induction, but Not Cell Viability through the Adapter Molecule Shc. J. Immunol., v.161, n.9, p.4627-33, 1998. 
LORD, J. D. et al. The II-2 Receptor Promotes Lymphocyte Proliferation and Induction of the $\mathrm{C}-\mathrm{Myc}, \mathrm{Bcl}-2$, and $\mathrm{Bcl}-\mathrm{X}$ Genes through the Trans-Activation Domain of Stat5. J. Immunol., v.164, n.5, p.2533-41, 2000.

LU, Y. et al. Signalling Events Mediating the Activation of Protein Kinase $\mathrm{C}$ by Interleukin-2 in Cytotoxic T Cells. Cell Signal., v.11, n.4, p.275-85, 1999.

LU, Z. H. et al. Saturated Free Fatty Acids, Palmitic Acid and Stearic Acid, Induce Apoptosis by Stimulation of Ceramide Generation in Rat Testicular Leydig Cell. Biochem. Biophys. Res. Commun., v.303, n.4, p.1002-7, 2003.

MADANI, S. et al. Implication of Acyl Chain of Diacylglycerols in Activation of Different Isoforms of Protein Kinase C. Faseb J., v.15, n.14, p.2595-601, 2001.

MANICASSAMY, S. et al. Selective Function of Pkc-Theta in T Cells. Cell Mol. Immunol., v.3, n.4, p.263-70, 2006.

MARSHALL, C. J. Specificity of Receptor Tyrosine Kinase Signaling: Transient Versus Sustained Extracellular Signal-Regulated Kinase Activation. Cell, v.80, n.2, p.179-85, 1995.

MASSAO HIRABARA, S. et al. Palmitate Acutely Raises Glycogen Synthesis in Rat Soleus Muscle by a Mechanism That Requires Its Metabolization (Randle Cycle). FEBS Lett., v.541, n.1-3, p.109-14, 2003.

MATSUMOTO, A. et al. Cis, a Cytokine Inducible Sh2 Protein, Is a Target of the Jak-Stat5 Pathway and Modulates Stat5 Activation. Blood, v.89, n.9, p.314854, 1997.

MIGLIETTA, A. et al. Extracellular Signal-Regulated Kinase 1/2 and Protein Phosphatase 2a Are Involved in the Antiproliferative Activity of Conjugated Linoleic Acid in Mcf-7 Cells. Br. J. Nutr., v.96, n.1, p.22-7, 2006.

MILES, E. A. et al. The Influence of Different Combinations of Gamma-Linolenic Acid, Stearidonic Acid and Epa on Immune Function in Healthy Young Male Subjects. Br. J. Nutr., v.91, n.6, p.893-903, 2004.

MOLINA, T. J. et al. Peripheral T Cells in Mice Lacking P56lck Do Not Express Significant Antiviral Effector Functions. J. Immunol., v.151, n.2, p.699-706, 1993.

MOLVIG, J. et al. Dietary Supplementation with Omega-3-Polyunsaturated Fatty Acids Decreases Mononuclear Cell Proliferation and Interleukin-1 Beta Content but Not Monokine Secretion in Healthy and Insulin-Dependent Diabetic Individuals. Scand. J. Immunol., v.34, n.4, p.399-410, 1991.

MOON, J. J., NELSON, B.H. Phosphatidylinositol 3-Kinase Potentiates, but Does Not Trigger, $T$ Cell Proliferation Mediated by the II-2 Receptor. J. Immunol., v.167, n.5, p.2714-2723, 2001. 
MURAKAMI, K. et al. Protein Kinase C Activation by Cis-Fatty Acid in the Absence of $\mathrm{Ca} 2+$ and Phospholipids. J. Biol. Chem., v.261, n.33, p.15424-9, 1986.

MUSTELIN, T. et al. Protein Tyrosine Phosphatases in T Cell Physiology. Mol. Immunol., v.41, n.6-7, p.687-700, 2004.

NAKANISHI, $\mathrm{H}$. et al. Activation of the Zeta Isozyme of Protein Kinase $\mathrm{C}$ by Phosphatidylinositol 3,4,5-Trisphosphate. J. Biol. Chem., v.268, n.1, p.13-6, 1993.

NAKANISHI, H.; EXTON, J. H. Purification and Characterization of the Zeta Isoform of Protein Kinase C from Bovine Kidney. J. Biol. Chem., v.267, n.23, p.16347-54, 1992.

NICOLETTI, I. et al. A Rapid and Simple Method for Measuring Thymocyte Apoptosis by Propidium lodide Staining and Flow Cytometry. J. Immunol. Methods, v.139, n.2, p.271-9, 1991.

OBEID, L. M. et al. Programmed Cell Death Induced by Ceramide. Science, v.259, n.5102, p.1769-71, 1993.

OKKENHAUG, K. et al. Phosphoinositide 3-Kinase in T Cell Activation and Survival. Biochem. Soc. Trans., v.32, n.Pt 2, p.332-5, 2004.

OTTON, R. et al. Effect of Dietary Fat on Lymphocyte Proliferation and Metabolism. Cell Biochem. Funct., v.16, n.4, p.253-9, 1998.

PAHWA, S.; MORALES, M. Interleukin-2 Therapy in Hiv Infection. AIDS Patient Care STDS, v.12, n.3, p.187-97, 1998.

PALOU, E. et al. Cd148, a Membrane Protein Tyrosine Phosphatase, Is Able to Induce Tyrosine Phosphorylation on Human Lymphocytes. Immunol. Lett., v.57, n.1-3, p.101-3, 1997.

PARK, S. H. et al. Serine Phosphorylation of Gh-Activated Signal Transducer and Activator of Transcription 5a (Stat5a) and Stat5b: Impact on Stat5 Transcriptional Activity. Mol. Endocrinol., v.15, n.12, p.2157-71, 2001.

PAUKKU, K.; SILVENNOINEN, O. Stats as Critical Mediators of Signal Transduction and Transcription: Lessons Learned from Stat5. Cytokine Growth Factor Rev., v.15, n.6, p.435-55, 2004.

PAUMEN, M. B. et al. Inhibition of Carnitine Palmitoyltransferase I Augments Sphingolipid Synthesis and Palmitate-Induced Apoptosis. J. Biol. Chem., v.272, n.6, p.3324-9, 1997.

PETRICOIN, E., 3RD et al. Inhibition of Alpha Interferon but Not Gamma Interferon Signal Transduction by Phorbol Esters Is Mediated by a Tyrosine Phosphatase. Mol. Cell Biol., v.16, n.4, p.1419-24, 1996. 
PIRCHER, T. J. et al. Extracellular Signal-Regulated Kinase (Erk) Interacts with Signal Transducer and Activator of Transcription (Stat) 5a. Mol. Endocrinol., v.13, n.4, p.555-65, 1999.

PIZZO, P. et al. Physiological T Cell Activation Starts and Propagates in Lipid Rafts. Immunol. Lett., v.91, n.1, p.3-9, 2004.

POMPEIA, C. et al. Effect of Fatty Acids on Leukocyte Function. Braz. J. Med. Biol. Res., v.33, n.11, p.1255-68, 2000.

RAVICHANDRAN, K. S. et al. Evidence for a Role for the PhosphotyrosineBinding Domain of Shc in Interleukin 2 Signaling. Proc. Natl. Acad. Sci. U.S.A., v.93, n.11, p.5275-80, 1996.

RAZZAQ, T. M. et al. Regulation of T-Cell Receptor Signalling by Membrane Microdomains. Immunology, v.113, n.4, p.413-26, 2004.

RICHIERI, G. V.; KLEINFELD, A. M. Free Fatty Acids Are Produced in and Secreted from Target Cells Very Early in Cytotoxic T Lymphocyte-Mediated Killing. J. Immunol., v.147, n.8, p.2809-15, 1991.

ROBB, R. J.; SMITH, K. A. Heterogeneity of Human T-Cell Growth Factor(S) Due to Variable Glycosylation. Mol. Immunol., v.18, n.12, p.1087-94, 1981.

ROULET, M. et al. Effects of Intravenously Infused Fish Oil on Platelet Fatty Acid Phospholipid Composition and on Platelet Function in Postoperative Trauma. JPEN J. Parenter. Enteral Nutr., v.21, n.5, p.296-301, 1997.

RUSSELL, S. M. et al. Interaction of II-2r Beta and Gamma C Chains with Jak1 and Jak3: Implications for Xscid and Xcid. Science, v.266, n.5187, p.1042-5, 1994.

SADEGHI, S. et al. Dietary Lipids Modify the Cytokine Response to Bacterial Lipopolysaccharide in Mice. Immunology, v.96, n.3, p.404-10, 1999.

SARBASSOV, D. D., et al. Phosphorylation and Regulation of Akt/Pkb by the Rictor-Mtor Complex. Science, v.307, n.5712, p.1098-101, 2005.

SASAKI, T. et al. Effects of Dietary Docosahexaenoic Acid on Surface Molecules Involved in T Cell Proliferation. Biochim. Biophys. Acta, v.1436, n.3, p.519-30, 1999.

SASAKI, T. et al. Phosphoinositide 3-Kinases in Immunity: Lessons from Knockout Mice. J. Biochem., v.131, n.4, p.495-501, 2002.

SATOH, T. et al. Involvement of Ras P21 Protein in Signal-Transduction Pathways from Interleukin 2, Interleukin 3, and Granulocyte/Macrophage Colony-Stimulating Factor, but Not from Interleukin 4. Proc. Natl. Acad. Sci. U.S.A., v.88, n.8, p.3314-8, 1991. 
SCHLEY, P. D. et al. (N-3) PUFA Alter Raft Lipid Composition and Decrease Epidermal Growth Factor Receptor Levels in Lipid Rafts of Human Breast Cancer Cells. J. Nutr., v.137, n.3, p.548-53, 2007.

SCHWIETERMAN, W. et al. Uptake of Oleate by Isolated Rat Adipocytes Is Mediated by a 40-Kda Plasma Membrane Fatty Acid Binding Protein Closely Related to That in Liver and Gut. Proc. Natl. Acad. Sci. U.S.A., v.85, n.2, p.359-63, 1988.

SEBALDT, R. J. et al. Quantification of Contributions of Phospholipid Precursors to Diradylglycerols in Stimulated Mononuclear Phagocytes. Biochem. J., v.284 ( Pt 2), p.367-75, 1992.

SEGER, R. et al. Differential Activation of Mitogen-Activated Protein Kinase and S6 Kinase Signaling Pathways by 12-O-Tetradecanoylphorbol-13-Acetate (Tpa) and Insulin. Evidence for Involvement of a TPA-Stimulated Protein-Tyrosine Kinase. J. Biol. Chem., v.270, n.47, p.28325-30, 1995.

SELBIE, L. A. et al. Molecular Cloning and Characterization of Pkc lota, an Atypical Isoform of Protein Kinase C Derived from Insulin-Secreting Cells. J. Biol. Chem., v.268, n.32, p.24296-302, 1993.

SENGUPTA, T. K. et al. Inhibition of Cytokines and Jak-Stat Activation by Distinct Signaling Pathways. Proc. Natl. Acad. Sci. U.S.A., v.93, n.18, p.9499504, 1996.

SHAIKH, S. R. et al. Interaction of Cholesterol with a Docosahexaenoic AcidContaining Phosphatidylethanolamine: Trigger for Microdomain/Raft Formation? Biochemistry, v.42, n.41, p.12028-37, 2003.

SHUAI, K. et al. Enhancement of Antiproliferative Activity of Gamma Interferon by the Specific Inhibition of Tyrosine Dephosphorylation of Stat1. Mol. Cell Biol., v.16, n.9, p.4932-41, 1996.

SIDDIQUI, R. A. et al. Docosahexaenoic Acid Induces Apoptosis in Jurkat Cells by a Protein Phosphatase-Mediated Process. Biochim. Biophys. Acta, v.1499, n.3, p.265-75, 2001.

SIMOPOULOS, A. P. The Importance of the Ratio of Omega-6/Omega-3 Essential Fatty Acids. Biomed. Pharmacother., v.56, n.8, p.365-79, 2002.

SMITH, K. A. The Interleukin 2 Receptor. Adv. Immunol., v.42, p.165-79, 1988.

SOYLAND, E.; DREVON, C. A. The Effect of Very Long-Chain N-3 Fatty Acids on Immune-Related Skin Diseases. Eur. J. Clin. Nutr., v.47, n.6, p.381-8, 1993.

STANLEY, J. B. et al. Tyrosine Phosphorylation Is an Obligatory Event in II-2 Secretion. J. Immunol., v.145, n.7, p.2189-98, 1990. 
STENTZ, F. B.; KITABCHI, A. E. Palmitic Acid-Induced Activation of Human TLymphocytes and Aortic Endothelial Cells with Production of Insulin Receptors, Reactive Oxygen Species, Cytokines, and Lipid Peroxidation. Biochem. Biophys. Res. Commun., v.346, n.3, p.721-6, 2006.

STULNIG, T. M., et al. Polyunsaturated Fatty Acids Inhibit T Cell Signal Transduction by Modification of Detergent-Insoluble Membrane Domains. J. Cell Biol., v.143, n.3, p.637-44, 1998.

SWANSON, R. V. et al. Histidine and Aspartate Phosphorylation: TwoComponent Systems and the Limits of Homology. Trends Biochem. Sci., v.19, n.11, p.485-90, 1994.

TEPPER, A. D. et al. Sphingomyelin Hydrolysis to Ceramide During the Execution Phase of Apoptosis Results from Phospholipid Scrambling and Alters Cell-Surface Morphology. J. Cell Biol., v.150, n.1, p.155-64, 2000.

THANASAK, J. et al. Effects of Polyunsaturated Fatty Acids on the Proliferation of Mitogen Stimulated Bovine Peripheral Blood Mononuclear Cells. Vet. Immunol. Immunopathol., v.104, n.3-4, p.289-95, 2005.

THIES, F. et al. Dietary Supplementation with Eicosapentaenoic Acid, but Not with Other Long-Chain N-3 or N-6 Polyunsaturated Fatty Acids, Decreases Natural Killer Cell Activity in Healthy Subjects Aged $>55$ Y. Am. J. Clin. Nutr., v.73, n.3, p.539-48, 2001.

TKACZUK, J. et al. Effect of Anti-II-2ralpha Antibody on II-2-Induced Jak/Stat Signaling. Am. J. Transplant., v.2, n.1, p.31-40, 2002.

TOKANO, Y. et al. Subsets of Activated T Cells in Patients with Systemic Lupus Erythematosus: The Relation to Cell Cycle. Scand. J. Rheumatol., v.26, n.1, p.37-42, 1997.

TOKUDOME, S. et al. Japanese Versus Mediterranean Diets and Cancer. Asian Pac. J. Cancer Prev., v.1, n.1, p.61-66, 2000.

TREISMAN, R. Regulation of Transcription by Map Kinase Cascades. Curr. Opin. Cell Biol., v.8, n.2, p.205-15, 1996.

TURNER, B. et al. Interleukin 2 Induces Tyrosine Phosphorylation and Activation of P72-74 Raf-1 Kinase in a T-Cell Line. Proc. Natl. Acad. Sci. U.S.A., v.88, n.4, p.1227-31, 1991.

VERI, M. C. et al. Membrane Raft-Dependent Regulation of Phospholipase Cgamma-1 Activation in T Lymphocytes. Mol. Cell Biol., v.21, n.20, p.6939-50, 2001.

VERLENGIA, R. et al. Effect of Arachidonic Acid on Proliferation, Cytokines Production and Pleiotropic Genes Expression in Jurkat Cells--a Comparison with Oleic Acid. Life Sci., v.73, n.23, p.2939-51, 2003. 
VERLENGIA, R. et al. Effects of Epa and Dha on Proliferation, Cytokine Production, and Gene Expression in Raji Cells. Lipids, v.39, n.9, p.857-64, 2004.

VOLKER, D. H. et al. The Eicosapentaenoic to Docosahexaenoic Acid Ratio of Diets Affects the Pathogenesis of Arthritis in Lew/Ssn Rats. J. Nutr., v.130, n.3, p.559-65, 2000.

WANG, $H$. et al. Ovarian Carcinoma Cells Inhibit $T$ Cell Proliferation: Suppression of II-2 Receptor Beta and Gamma Expression and Their Jak-Stat Signaling Pathway. Life Sci., v.74, n.14, p.1739-49, 2004.

WATTS, T. H.; DEBENEDETTE, M. A. T Cell Co-Stimulatory Molecules Other Than Cd28. Curr. Opin. Immunol., v.11, n.3, p.286-93, 1999.

WEITBERG, A. B. Effects of Arachidonic Acid and Inhibitors of Arachidonic Acid Metabolism on Phagocyte-Induced Sister Chromatid Exchanges. Clin. Genet., v.34, n.5, p.288-92, 1988.

WEN, Z.; DARNELL, J. E., JR. Mapping of Stat3 Serine Phosphorylation to a Single Residue (727) and Evidence That Serine Phosphorylation Has No Influence on DNA Binding of Stat1 and Stat3. Nucleic Acids Res., v.25, n.11, p.2062-7, 1997.

WHITMARSH, A. J.; DAVIS, R. J. Regulation of Transcription Factor Function by Phosphorylation. Cell Mol. Life Sci., v.57, n.8-9, p.1172-83, 2000.

WILLIAMS, K. I.; HIGGS, G. A. Eicosanoids and Inflammation. J. Pathol., v.156, n.2, p.101-10, 1988.

WILLIAMS, W. V. et al. Effects of Unsaturated Fatty Acids on Expression of Early Response Genes in Human T Lymphocytes. Pathobiology, v.64, n.1, p.27-31, 1996.

XAVIER, R.; SEED, B. Membrane Compartmentation and the Response to Antigen. Curr. Opin. Immunol., v.11, n.3, p.265-9, 1999.

XUE, H. et al. Eicosapentaenoic Acid and Docosahexaenoic Acid Modulate Mitogen-Activated Protein Kinase Activity in Endothelium. Vascul. Pharmacol., v.44, n.6, p.434-9, 2006.

YANEY, G. C. et al. Long-Chain Acyl Coa Regulation of Protein Kinase C and Fatty Acid Potentiation of Glucose-Stimulated Insulin Secretion in Clonal BetaCells. Endocrinology, v.141, n.6, p.1989-98, 2000.

YAQOOB, P. Monounsaturated Fats and Immune Function. Braz. J. Med. Biol. Res., v.31, n.4, p.453-65, 1998.

YOUNG, V. M. et al. Effect of Linoleic Acid on Endothelial Cell Inflammatory Mediators. Metabolism, v.47, n.5, p.566-72, 1998. 
ZEIDLER, H. K. et al. Progression of Joint Damage in Early Active Severe Rheumatoid Arthritis During 18 Months of Treatment: Comparison of Low-Dose Cyclosporin and Parenteral Gold. Br. J. Rheumatol., v.37, n.8, p.874-82, 1998.

ZERR, K. J. et al. Glucose Control Lowers the Risk of Wound Infection in Diabetics after Open Heart Operations. Ann. Thorac. Surg., v.63, n.2, p.35661, 1997.

ZHANG, X. et al. Requirement of Serine Phosphorylation for Formation of StatPromoter Complexes. Science, v.267, n.5206, p.1990-4, 1995.

ZHANG, Z. et al. The Role of C-Terminal Tyrosine Phosphorylation in the Regulation of Shp-1 Explored Via Expressed Protein Ligation. J. Biol. Chem., v.278, n.7, p.4668-74, 2003.

ZHANG, Z. Y. et al. Modulation of Protein Kinase Signaling by Protein Phosphatases and Inhibitors. Pharmacol. Ther., v.93, n.2-3, p.307-17, 2002. 